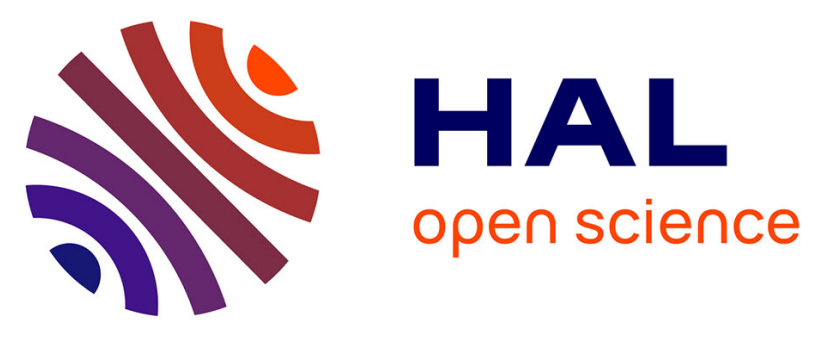

\title{
A microRNA switch regulates the rise in hypothalamic GnRH production before puberty
}

Andrea Messina, Fanny Langlet, Konstantina Chachlaki, Juan Roa, Sowmyalakshmi Rasika, Nathalie Jouy, Sarah Gallet, Francisco Gaytan, Jyoti Parkash, Manuel Tena-Sempere, et al.

\section{To cite this version:}

Andrea Messina, Fanny Langlet, Konstantina Chachlaki, Juan Roa, Sowmyalakshmi Rasika, et al.. A microRNA switch regulates the rise in hypothalamic GnRH production before puberty. Nature Neuroscience, 2016, 19 (6), pp.835-844. 10.1038/nn.4298 . inserm-03204447v2

HAL Id: inserm-03204447 https://www.hal.inserm.fr/inserm-03204447v2

Submitted on 22 Apr 2021

HAL is a multi-disciplinary open access archive for the deposit and dissemination of scientific research documents, whether they are published or not. The documents may come from teaching and research institutions in France or abroad, or from public or private research centers.
L'archive ouverte pluridisciplinaire HAL, est destinée au dépôt et à la diffusion de documents scientifiques de niveau recherche, publiés ou non, émanant des établissements d'enseignement et de recherche français ou étrangers, des laboratoires publics ou privés. 
Submission: April 22, 2021

NN-A50950

\section{MicroRNAs flip the switch for the production of hypothalamic GnRH before puberty}

Andrea Messina $^{1,2}$, Fanny Langlet ${ }^{1,2,3}$, Konstantina Chachlaki ${ }^{1,2}$, Juan Roa ${ }^{4,5}$, S Rasika ${ }^{1}$, Nathalie Jouy ${ }^{1,2}$, Sarah Gallet ${ }^{1,2}$, Jyoti Parkash ${ }^{1,2}$, Manuel Tena-Sempere ${ }^{4,5}$, Paolo Giacobini $^{1,2}$, Vincent Prevot ${ }^{1,2^{*}}$

${ }^{1}$ Inserm, Laboratory of Development and Plasticity of the Neuroendocrine Brain, Jean-Pierre Aubert Research Centre, UMR1172, F-59000 Lille, France

${ }^{2}$ University of Lille, School of Medicine, Lille, F-59000, France

${ }^{3}$ Columbia University Medical Center and Berrie Diabetes Center, New York, NY 10032 , USA

${ }^{4}$ Department of Cell Biology, Physiology and Immunology, University of Cordoba \& Instituto Maimonides de Investigación Biomédica de Cordoba (IMIBIC/HURS), 14004 Cordoba, Spain

${ }^{5}$ CIBER Fisiopatología de la Obesidad y Nutrición, Instituto de Salud Carlos III, 14004 Cordoba, Spain

$¥$ These authors contributed equally to this work

* Corresponding author: Vincent Prevot, Ph.D., Inserm U1172, Bâtiment Biserte, Place de Verdun, 59045 Lille Cedex, France

Tel : +33 612-90-38-76

E-mail : vincent.prevot@inserm.fr 


\begin{abstract}
A sparse population of a few hundred primarily hypothalamic neurons forms the hub of a complex neuroglial network that controls reproduction in mammals by secreting the "master molecule", gonadotropin-releasing hormone $(\mathrm{GnRH})$. Timely postnatal changes in $\mathrm{GnRH}$ expression are essential for puberty and adult fertility. Here, we report that a multilayered microRNA-operated switch with inbuilt feedback controls governs increased $\mathrm{GnRH}$ expression during the infantile-juvenile transition, and that impairing microRNA synthesis in $\mathrm{GnRH}$ neurons leads to hypogonadotropic hypogonadism and infertility in mice. Two essential components of this switch, miR-200 and miR-155, respectively regulate Zeb1, a repressor of $G n R H$ transcriptional activators and $G n R H$ itself, and Cebpb, an NO-mediated repressor of $\mathrm{GnRH}$ that acts both directly and through Zeb1, in $\mathrm{GnRH}$ neurons. This alteration in the delicate balance between inductive and repressive signals induces the normal $\mathrm{GnRH}$-fuelled run-up to correct puberty initiation, and interfering with this process disrupts the neuroendocrine control of reproduction.
\end{abstract}




\section{Introduction}

The onset of puberty and the regulation of fertility in mammals are governed by a complex neural network, primarily in the hypothalamus, that converges onto gonadotropin-releasing hormone $(\mathrm{GnRH})$-producing neurons, the master regulators of gonadotropin secretion and postnatal gonadal growth and function ${ }^{1}$. The proper development of the GnRH system ${ }^{2}$, including timely changes in $\mathrm{GnRH}$ expression and signaling by this sparse population of a few hundred neurons ${ }^{3,4}$, is essential for sexual maturation and the normal functioning of the hypothalamic-pituitary-gonadal axis. However, despite the identification of several factors influencing $\mathrm{GnRH}$ production and release ${ }^{5-9}$, the mechanisms regulating the clocklike precision of the pubertal activation process remain mysterious.

MicroRNAs (miRNAs) are short ( 22-nucleotide) noncoding RNA molecules that silence gene expression posttranscriptionally, principally by binding to the 3' untranslated regions (3'UTR) of target mRNAs (Fig. S1). Mature miRNAs have been shown to be required for the normal differentiation and function of several different cell types ${ }^{10-13}$ and, in particular, to regulate somatic growth and fertility at the level of peripheral organs ${ }^{14-16}$. We therefore asked whether miRNAs could play a similarly critical role in the central neuroendocrine control of reproduction.

Here we show that a dramatic switch in miRNA expression patterns in infantile GnRH neurons inverts the balance between inductive and repressive signals, triggering an increase in hypothalamic $\mathrm{GnRH}$ expression and thereby controlling the crucial transition from the early infantile phase, when its levels are low, to the $\mathrm{GnRH}$-fuelled run-up to puberty. These data raise the intriguing possibility that the miRNA-dependent epigenetic regulation of $\mathrm{GnRH}$ secretion could underlie the pathophysiology of human hypogonadotropic hypogonadism when a genetic cause is not evident, and hold therapeutic potential for disorders of puberty and infertility of hypothalamic origin. 


\section{Results}

Loss of Dicer function in GnRH neurons causes postnatal defects leading to hypogonadotropic hypogonadism and infertility

To determine whether miRNAs play a role in the crucial postnatal increase in $\mathrm{GnRH}$ expression, we generated mice in which Dicer, an RNAse III endonuclease essential for miRNA biogenesis ${ }^{17}$, was selectively inactivated in $\mathrm{GnRH}$ neurons. Animals harboring a floxed Dicer allele ${ }^{12}$ were crossed with those expressing Cre recombinase under the control of the endogenous $\mathrm{GnRH}$ promoter ${ }^{18}$ (Fig. 1A), which is expressed in hypothalamic GnRH neurons but not in the gonads (Fig. S2A,B). The resulting Gnrh::Cre; Dicer ${ }^{\text {JoxP/loxP }}$ mice were viable, born at Mendelian frequencies, and had body weights at adulthood indistinguishable from Dicer ${ }^{\text {JoxP/loxP }}$ (wild-type) littermates $\left(\mathrm{t}_{(8)}=4.35, \mathrm{p}=0.390, \mathrm{n}=5\right.$ per group). All male and female mutant mice, however, exhibited severe hypogonadism (testicular weight: $t_{(13)}=24.4$, $p=0.0001, n=5-10$ per group; uterine weight: $t_{(4.47)}=10.2, p=0.0005, n=5-6$ per group) (Fig. 1BE) and sterility (males: $n=6$; females: $n=6$ ) (Fig. 1F). While some female Gnrh::Cre; Dicer $^{\operatorname{loxP} / \text { loxP }}$ mice underwent vaginal opening (5 of 7) (Fig. 1G), this external sign of sexual maturation occurred significantly later than in Dicer ${ }^{\text {loxP/loxP }}$ mice $\left(t_{(14)}=-4.93, p=0.0002\right)$, and vaginal smears showed that they never reached puberty $(n=7)($ Fig. $1 \mathrm{H})$ despite normal somatic growth (two-way ANOVA, $\mathrm{F}_{(1.96,11.96)}=0.5741, \mathrm{p}=0.54, \mathrm{n}=5$ per group) (Fig. 1I). Similarly, male Gnrh::Cre; Dicer ${ }^{\text {loxP/loxP }}$ mice $(n=5)$ did not exhibit balanopreputial separation, which occurred at $34.9 \pm 1.8$ days of age in Dicer ${ }^{\text {loxP/loxP }}$ littermates $(n=11)$, or spermatozoa in the seminiferous tubules (Fig. 1C). Additionally, serum levels of the pituitary gonadotropins luteinizing hormone (LH) and follicle-stimulating hormone (FSH) were markedly reduced in adult mutants (Fig. S2C,D). LH levels could readily be increased by systemic $\mathrm{GnRH}$ injection, demonstrating that pituitary function in our Gnrh::Cre; Dicer ${ }^{\text {loxP/loxP }}$ mice was intact (Fig. S2E). However, LH levels were unaffected by the intracerebroventricular infusion of two potent stimulators of the GnRH system that trigger LH release in wild-type animals: kisspeptin, which acts through its receptor Gpr54, and NMDA, which bypasses the kisspeptidergic system to act directly on $\mathrm{GnRH}$ neurons ${ }^{9,19}$ (Fig. S2F,G), suggesting that the 
hypogonadotropic hypogonadism observed was due primarily to a hypothalamic $\mathrm{GnRH}$ deficiency.

Following these physiological data, neuroanatomical analyses revealed a striking and complete absence of $\mathrm{GnRH}$ immunoreactivity in the hypothalamus of adult mutant mice (Fig. $\mathrm{S} 3 \mathrm{~A}, \mathrm{~B})$, reminiscent of Kallmann syndrome in humans ${ }^{2}$, in which $\mathrm{GnRH}$ neurons, which originate in the olfactory placode, fail to migrate into the brain during development. To determine whether Dicer invalidation in mouse $\mathrm{GnRH}$ neurons similarly affected their migration, we examined them on embryonic day $(E)$ 14.5, when half the migrating $\mathrm{GnRH}$ neurons are still in the nose, and at birth (postnatal day $0, \mathrm{P} 0$ ), when $\mathrm{GnRH}$ neurons have completed their migration into the hypothalamic preoptic region, their principal site of residence, and sent projections to the median eminence, where they release their neurohormone into portal capillaries for delivery to the anterior pituitary ${ }^{20,21}$. Surprisingly, and unlike the case in Kallmann patients, $\mathrm{GnRH}$ neurons displayed no migratory defects and $\mathrm{GnRH}$ immunoreactivity was comparable in Gnrh::Cre; Dicer ${ }^{\text {loxP/loxP }}$ and Dicer roxP/loxP littermates at $\mathrm{PO}\left(\mathrm{t}_{(4)}=0.27, \mathrm{p}=0.8, \mathrm{n}=3\right.$ per group) (Fig. S4). GnRH deficiency in mutant mice was thus not due to a developmental lack of $\mathrm{GnRH}$ neurons, but acquired postnatally.

The GnRH peptide content of the hypothalamus increases progressively between birth and puberty, accelerating markedly during the latter part of the infantile period (P7-P12) ${ }^{7}$. We thus examined hypothalamic $\mathrm{GnRH}$ immunoreactivity at different postnatal ages and found that its disappearance in Gnrh::Cre; Dicer loxP/loxP mice occurred gradually, starting during the infantile period $\left(t_{(10)}=1.96, p=0.08, n=5-7\right.$ per group at $\left.P 12\right)$ (Fig. 2A, Fig. S5) and becoming more rapid after weaning, during the juvenile period, i.e. P21 to $\sim P 35\left(t_{(11)}=8.53\right.$, $\mathrm{p}<0.0001, \mathrm{n}=6-7$ per group at $\mathrm{P} 21$ and $\mathrm{t}_{(6.59)}=10.98, \mathrm{p}<0.0001, \mathrm{n}=7-9$ per group at P28) (Fig. 2A, Fig. S5). Unexpectedly, however, the generation of Gnrh::Cre; Dicer ${ }^{\text {loxP/loxP; }}$ td Tomato ${ }^{\text {loxP/STOP }}$ trigenic mice, in which the tracer tdTomato continues to be expressed in $\mathrm{GnRH}$ neurons even without ongoing $\mathrm{GnRH}$ promoter activity, revealed that in the absence of miRNAs, GnRH neurons did not die but simply lost $\mathrm{GnRH}$ immunoreactivity (Fig. 2B). Indeed, at P21, 70\% of $\mathrm{GnRH}$ neurons had lost $\mathrm{GnRH}$ peptide expression in Gnrh::Cre; 
Dicer $^{\text {loxP/loxP }} ;$ td Tomato ${ }^{\text {loxP/STOP }}$ mice when compared to Gnrh::Cre; Dicer ${ }^{+/+}$; td Tomato ${ }^{\text {loxP/STOP }}$ littermates. Importantly, the concomitant loss of $\mathrm{GnRH}$ immunoreactivity and green fluorescent protein (GFP) in Gnrh::Gfp; Gnrh::Cre; Dicer ${ }^{\text {loxP/loxP }}$ mice (Fig. S3C), in which GFP is expressed under the $\mathrm{GnRH}$ promoter (unlike tdTomato in the previous experiment), indicated that miRNAs probably did not regulate $\mathrm{GnRH}$ transcript stability and/or translation directly by binding to its 3'UTR, but rather affected genes necessary for GnRH transcription, such as promoter modulators.

\section{An infantile switch in miRNA species induces GnRH promoter activator expression in}

\section{GnRH neurons in vivo}

In order to tease apart the mechanism of miRNA action, we started by verifying the expression profile of the $\mathrm{GnRH}$ transcript in $\mathrm{GnRH}$ neurons isolated by FACS from Gnrh::Gfp mice wild-type for Dicer at two stages: P7, the beginning of the infantile period, and P12, when hypothalamic $\mathrm{GnRH}$ peptide content begins to increase in a functionally relevant manner in normal mice ${ }^{7}$, whereas it begins to decrease in mice lacking Dicer even though the vast majority of their $\mathrm{GnRH}$ neurons ( $80 \%$ ) still express enough GFP to be detectable (Fig. S3). Real-time PCR analyses of GFP-expressing GnRH neurons isolated by fluorescence-activated cell sorting (FACS) from Gnrh::Gfp; DiceroxP/loxP mice (Fig. 2C; Fig. S6) revealed that there was a $200 \%$ increase in $\mathrm{GnRH}$ mRNA levels between P7 and P12 in these Dicer wild-type mice $\left(t_{(5)}=-3.20, p=0.024, n=3-4\right.$ per group) (Fig 2D). This increase was accompanied by a significant upregulation of the mRNA levels of several promoter activators known to affect $\mathrm{GnRH}$ expression ${ }^{22,23}$ (Fig. 2E), while transcripts of three known $\mathrm{GnRH}$ repressors ${ }^{22,23}$ remained unchanged (Fig. 2F). However, in $\mathrm{GnRH}$ neurons lacking Dicer isolated from Gnrh::Gfp; Gnrh::Cre; DiceroxPloxP trigenic mice at P12, GnRH mRNA expression was significantly lower than in neurons from Dicer wild-type Gnrh::Gfp; Dicer $^{\text {JoxPlloxP }}$ mice $\left(\mathrm{t}_{(3.12)}=5.88, \mathrm{p}=0.0098, \mathrm{n}=4\right.$ per group) (Fig. $\left.2 \mathrm{G}\right)$. In addition, there was a marked decrease in the expression of most GnRH promoter activators (Fig. 3A) and a striking 15-fold increase in the transcript of the $\mathrm{GnRH}$ promoter repressor Cebpb (Fig. 3B) in 
GnRH neurons in the absence of Dicer (Fig. 3A,B). In silico analysis of the 3'UTR sequence of these promoter modulators revealed the presence of putative binding sites for several miRNAs $(p<0.01$; Table S1), confirming that miRNAs could regulate the expression of these genes. Concordantly, we uncovered a dramatic inversion of the expression profile of these and other putative regulatory miRNAs in wild-type GnRH neurons between P7 and P12 (Fig. $3 \mathrm{C})$, strongly suggesting that $\mathrm{GnRH}$ promoter activity during the infantile period is controlled by a switch operated by miRNAs.

\section{The miR-200/Zeb1 network is involved in controlling hypothalamic GnRH expression during postnatal development}

The decrease in the expression of $\mathrm{GnRH}$ promoter activators uncovered above suggests that in the absence of miRNAs, repressors of these activators might be reciprocally increased. To identify the putative molecular targets involved in this process, we looked for miRNAs differentially expressed between P7 and P12 (Fig. 3C) that were also specifically enriched in GnRH neurons. The results showed that members of the miRNA-200 family, including miR141 and miR-429 (Fig. S7A), were among the most highly expressed miRNAs in infantile GnRH neurons when compared to non-GnRH-expressing cells (Fig. 3D and 3E). Within this family, the expression of miR-200a and miR-429, known to silence the mRNA for the transcriptional repressor Zeb1 outside the brain in pituitary gonadotropes, where it regulates LH expression ${ }^{14}$, increased significantly between P7 and P12 (miR-200a, $\mathrm{t}_{(4)}=9.178$, $\mathrm{p}=0.0008 ; \operatorname{miR}-429, \mathrm{t}_{(5)}=3.931, \mathrm{p}=0.0111, \mathrm{n}=3-4$ per group) (Fig $3 \mathrm{~F}$ ). To explore the possibility that the miR-200/Zeb1 network ${ }^{24}$ (Fig. S7A) also controlled hypothalamic GnRH expression during postnatal development, we analyzed Zeb1 expression in the brain of mice that did or did not express miRNAs in GnRH neurons. Importantly, not only was Zeb1 mRNA expressed in infantile $\mathrm{GnRH}$ neurons, its expression decreased significantly between $\mathrm{P} 7$ and P12 in Gnrh::Gfp; Dicer ${ }^{+++}$mice $\left(\mathrm{t}_{(6)}=4.86, \mathrm{p}=0.0028, \mathrm{n}=4\right.$ per group) (Fig. 4A). RT-PCR experiments in GnRH neurons isolated from Gnrh::Gfp; Gnrh::Cre; Dicer ${ }^{\text {loxP/loxP }}$ and Gnrh::Gfp; Dicer ${ }^{\text {loxP/loxP }}$ littermates at P12 further showed that Zeb1 mRNA was significantly 
upregulated in mutant mice $\left(\mathrm{t}_{(5)}=-3.38, \mathrm{p}=0.0195, \mathrm{n}=3-4\right.$ per group) (Fig. 4B). In silico sequence analysis revealed varying numbers of putative Zeb1-binding sites in the genes of all $\mathrm{GnRH}$ transcriptional activators under scrutiny (Fig. S7B), including Pou2f1, which in addition to activating the $\mathrm{GnRH}$ gene directly, could increase levels of miR-200 ${ }^{25}$, thereby indirectly influencing $\mathrm{GnRH}$ activation by repressing Zeb1. In addition, the $\mathrm{GnRH}$ gene itself was found to contain putative Zeb1-binding sites, three of which we validated as being functionally active using chromatin immunoprecipitation assays in an immortalized $\mathrm{GnRH}$ expressing mouse cell line (Fig. 4C). Altogether these data support the idea that increased Zeb1 expression in the absence of miRNA biogenesis could mediate the downregulation of these activators and of $\mathrm{GnRH}$ in these neurons (Fig. 3A). To test this hypothesis, we infused a target-site blocker, TSB-200, into the brains of Gnrh::Gfp; Dicer ${ }^{+/+}$mice to selectively hamper the binding of miR-200b/200c/429 to Zeb1 mRNA (Fig. S7C). TSBs are small, stabilized, freely diffusible locked nucleic acid (LNA) oligonucleotides, complementary to both the miRNA and the binding site being targeted (see for example Fig. S8C, D, E). As shown by fluorescence-tagged sequences (Fig. S8A), TSBs readily target the preoptic region and $\mathrm{GnRH}$ neurons $72 \mathrm{~h}$ after their infusion into the lateral ventricle of Gnrh::Gfp; Dicer ${ }^{+/+}$pups. TSB-200 treatment significantly increased Zeb1 mRNA levels in GnRH neurons as compared to a scrambled sequence $\left(t_{(9)}=-3.33, p=0.0087, n=5-6\right.$ per group) (Fig. 4D), but did not affect the transcripts of two other miR-200b/200c/429 target genes, Lpin1 ${ }^{26}\left(\mathrm{t}_{(10)}=0.663, \mathrm{p}=0.52\right.$, $\mathrm{n}=6$ per group) and $\operatorname{Maf}^{27}\left(\mathrm{t}_{(10)}=-0.192, \mathrm{p}=0.85, \mathrm{n}=6\right.$ per group) (Fig. 4D). This increase in Zeb1 expression was accompanied by a significant decrease in the induction of transcripts for two $\mathrm{GnRH}$ promoter activators that were upregulated in $\mathrm{GnRH}$ neurons at $\mathrm{P} 12$ compared to P7 (Fig. 2E), Meis1 $\left(\mathrm{t}_{(8)}=2.53, \mathrm{p}=0.035, \mathrm{n}=5\right.$ per group) and Pou2f1 $\left(\mathrm{t}_{(10)}=4.15, \mathrm{p}=0.002\right.$, $\mathrm{n}=6$ per group) (Fig. 4E), while transcripts for other known promoter activators, such as Aes, Otx2, Pbx1 and Pknox1, which did not significantly change between P7 and P12, were also unchanged by TSB-200 infusion. Interestingly, these genes also had fewer putative Zeb1binding sites than those whose expression was strongly modified by altered Zeb1 expression (Fig. S7B). As expected, GnRH transcription was also downregulated by the blockade of 
miR-200 binding to Zeb1 at P12 $\left(\mathrm{t}_{(9)}=5.37, \mathrm{p}=0.0004, \mathrm{n}=4-7\right.$ per group) (Fig. 4F). This repressive effect on $\mathrm{GnRH}$ mRNA levels was apparently mediated by the inhibition of $\mathrm{GnRH}$ promoter activity, as shown by the dramatic decrease in Gfp reporter mRNA expression $\left(t_{(10)}=14.1, p<0.0001, n=6\right.$ per group) (Fig. $4 G$ ), suggesting that the miR-200/Zeb1 network is actively involved in the switch in the control of $\mathrm{GnRH}$ transcription in the infantile mouse hypothalamus (Fig. 4H).

\section{Hampering selective miR-155 binding to the GnRH repressor Cebpb activates Zeb-1 expression and inhibits infantile GnRH promoter activity in vivo}

In contrast to the downregulation of $\mathrm{GnRH}$ promoter activators in mice lacking Dicer in $\mathrm{GnRH}$ neurons, the mRNA for a GnRH repressor, Cebpb, which codes for the CAAT/enhancer binding protein $\beta$ (C/EBP $\beta$ ), was found to be dramatically upregulated (see Fig. 3B above). We thus reasoned that the repression of C/EBP $\beta$ expression by miRNAs would increase radically during the infantile period in wild-type mice. Using the miRWalk database, which provides validated information on miRNA-target interactions ${ }^{28}$, we found that among the miRNAs upregulated in GnRH neurons at P12 (Fig. 3C, 3D) was miR-155, whose seed region targets the $3^{\prime} U T R$ of the Cebpb transcript $\left(p<0.01\right.$, Table S2, Fig. S8B,C) ${ }^{29}$. To determine whether the ten-fold increase in miR-155 expression between P7 and P12 $\left(t_{(4)}=-\right.$ 4.85, $\mathrm{p}=0.0083, \mathrm{n}=3$ per group) (Fig. $5 \mathrm{~A}$ ) played an actual role in regulating $\mathrm{C} / \mathrm{EBP} \beta$ expression in $\mathrm{GnRH}$ neurons, we used TSB-155 to selectively hamper miR-155 binding to the Cebpb transcript in the hypothalamus of infantile mice (Fig. S8D, S8E). TSB-155 infusion into Gnrh::Gfp; Dicer $^{+++}$mice markedly increased the levels of Cebpb mRNA in GnRH neurons when compared to a scrambled sequence $\left(t_{(9)}=-3.41, p=0.0038, n=5-6\right.$ per group) (Fig. 5B), but did not change mRNA levels of $L$ pin1 $\left(\mathrm{t}_{(10)}=0.601, \mathrm{p}=0.56, \mathrm{n}=6\right.$ per group) and Maf $\left(\mathrm{t}_{(10)}=0.406, \mathrm{p}=0.69, \mathrm{n}=6\right.$ per group) (Fig. $\left.5 \mathrm{~B}\right)$, which are also validated targets for miR$155^{30,31}$. Importantly, this TSB-155-mediated upregulation of the Cebpb transcript was associated with a strong inhibition of both $\mathrm{GnRH}$ promoter activity, as indicated by Gfp 
mRNA levels $\left(t_{(10)}=14, p<0,0001, n=6\right.$ per group) (Fig. $\left.5 C\right)$ and $G n R H$ mRNA levels $\left(t_{(8)}=3.57\right.$, $\mathrm{p}=0.0073, \mathrm{n}=4-6$ per group) (Fig. 5D). Surprisingly, we found, using ChIPBase, an integrated resource and platform for decoding transcription factor binding maps based on ChipSeq data ${ }^{32}$, that the Zeb1 gene contained binding sites for C/EBP $\beta$ in six different regulatory regions ${ }^{33,34}$ (Fig. S9) but no binding site for miR-155, suggesting that C/EBP $\beta$ could regulate $\mathrm{GnRH}$ mRNA levels not only directly but indirectly, by influencing Zeb1 expression. In agreement with this hypothesis, TSB-155 treatment, which selectively upregulates the Cebpb transcript, also increased Zeb1 mRNA expression in Dicer $^{+/+}$GnRH neurons $\left(\mathrm{t}_{(9)}=-2.89, \mathrm{p}=0.0177, \mathrm{n}=5\right.$ 6 per group) (Fig. 5E). Furthermore, in silico and ChipSeq analysis revealed several binding sites for both C/EBP $\beta$ - and Zeb1 on the Gpr54 gene (Fig. S7B and Fig. S9), suggesting that in addition to their direct and promoter-activator-mediated effects, C/EBP $\beta$ and Zeb1 could repress $\mathrm{GnRH}$ gene transcription indirectly by blocking kisspeptinergic signaling through Gpr54, which has been shown to promote the nuclear translocation of the GnRH promoter activator Otx2 and the subsequent increase in $\mathrm{GnRH}$ transcription ${ }^{35}$ (Fig. 5F). In support of this hypothesis, RT-PCR analysis revealed that in animals lacking Dicer in GnRH neurons, Gpr54 mRNA levels were also strongly reduced $\left(\mathrm{t}_{(6)}=4.22, \mathrm{p}=0.0056, \mathrm{n}=4\right.$ per group) (Fig. $5 G$ ), to a similar extent as that of other $\mathrm{GnRH}$ activators (Fig. 3A).

\section{Blockade of infantile NO release partially rescues GnRH expression in GnRH neurons lacking functional Dicer}

$\mathrm{C} / \mathrm{EBP} \beta$ is also known to mediate the nitric oxide (NO) -induced repression of $\mathrm{GnRH}$ gene expression ${ }^{22}$. However, we have recently shown that the activation of neuronal NO synthase (nNOS) in neurons of the preoptic region, itself regulated by the actions of Kisspeptin on its receptor Gpr54 ${ }^{36}$, is required for sexual maturation ${ }^{37}$. Intriguingly, in wild-type mice in the present study, nNOS activity increased significantly in the preoptic region between P7 and $\mathrm{P} 12$, at a time when synaptic connectivity is being established in the $\mathrm{GnRH}$ neuronal network ${ }^{38,39}$, as shown by the increase in the phosphorylation of its Ser1412 activation site ${ }^{40}$ (p- 
$\mathrm{nNOS} / \mathrm{NOS}$ ratio, $\mathrm{t}_{(6)}=-5.48, \mathrm{p}=0.0015, \mathrm{n}=4$ per group) (Fig. $5 \mathrm{H}$ ). To determine whether the marked decrease in $\mathrm{GnRH}$ expression in mice lacking Dicer could be related to this infantile increase in NO-C/EBP $\beta$ signaling, we next treated P12 Gnrh::Gfp; Gnrh::Cre; DicerloxP/loxP mice with the NOS inhibitor N-G-Nitro-L-arginine methyl ester (L-NAME; $50 \mathrm{mg} / \mathrm{kg}$, i.p.) and assessed GnRH mRNA expression in FACS-isolated neurons $12 \mathrm{~h}$ later. The reduced production of $\mathrm{NO}$ due to L-NAME treatment partially but significantly rescued $\mathrm{GnRH}$ transcript levels $(t(8)=-2.40, p=0.043, n=6-7$ per group) (Fig. $5 \mathrm{I})$. In addition to the alleviation of the previously demonstrated repressive effect of C/EBP $\beta$ on the GnRH promoter ${ }^{22}$, this increase in $\mathrm{GnRH}$ expression could have resulted from the inhibition of the transcriptional activation of Zeb1 by C/EBP $\beta$, as suggested by the 2.4-fold increase in transcripts for Pou2f1 (in L-NAME-injected vs. saline-injected mice; $\mathrm{t}(8)=-1.40, \mathrm{p}=0.017, \mathrm{n}=5-6$ per group). This suggests that increased NO levels during this period crucial for subsequent $\mathrm{GnRH}$ neuronal function might actually participate in the multilayered transcriptional repression of the Gnrh gene in the absence of posttranscriptional silencing of C/EBP $\beta$ by miRNAs (Fig. 5J). In other words, not only do miRNAs control the switch in $\mathrm{GnRH}$ promoter activity in infantile $\mathrm{GnRH}$ neurons, and thus reproductive capacity, they do so through an intricate mechanism involving crosstalk between inductive and repressive pathways.

miR-200 family members bind to Zeb-1 to control GnRH neuronal function throughout life

To assess the functional involvement of miR-200 family members and miR-155 in GnRH neurons in the onset of puberty, we performed a single bolus injection of the same TSB-200 and/or TSB-155 into the brains of female wild-type mice at P9, and monitored sexual maturation after weaning. Importantly, the use of fluorescently-labeled TSBs demonstrated that they could be detected in the brain up to 2 weeks after injection (Fig. S8A). Surprisingly, while growth (Fig S10) was similar in TSB- and scrambled-sequence-injected mice, TSBinjected mice exhibited a precocious onset of puberty when compared to control mice (Fig. 6A). This effect was most pronounced in TSB-200-infused mice, with $50 \%$ of the animals 
displaying their first estrus by P32, i.e. more than 10 days before control mice. In line with these results, TSB-200-infused mice showed significantly elevated peripubertal afternoon surges of plasma LH at P38, while changes in LH levels induced by TSB-155 treatment did not reach statistical significance when compared to control mice, in which plasma LH levels were below the limit of detection (Fig.6B). The combination of TSB-200 and TSB-155 also increased LH to detectable levels, although this effect was minimal (Fig. 6B; $F(3,32)=3.475$, $p=0.0272, n=8-10$ per group; TSB-200, $p=0.0361$; TSB-155, $p=0.7541 ;$ TSB-200+TSB-155, $\mathrm{p}=0.9996$ ) and resulted in earlier puberty onset by about 5 days when compared to control mice. In keeping with its lack of a significant effect on LH levels, treatment with TSB-155 alone failed to significantly change age at puberty (Fig. $6 A ; F(3,35)=4.961, p=0.0057, n=9$ 10 per group; TSB-200, $\mathrm{p}=0.0019$; TSB-155, $\mathrm{p}=0.073$; TSB-200+TSB-155, $\mathrm{p}=0.0328$ ). To verify whether this discrepancy in the impact of blocking either miR-200/429-Zeb1 binding or miR-155-Cebpb binding on GnRH promoter activity at P12 (Fig. 4F, 4G and Fig. 5C, 5D, respectively) and on subsequent sexual maturation (Fig 6A) was linked to differences in the specific cell types targeted by TSB-155 and TSB-200 in the hypothalamus, we analyzed the effects of TSB injection on the expression of Cebpb and Zeb1 in non-GnRH cells at P12. In agreement with the level of enrichment of miRNA expression in $\mathrm{GnRH}$ neurons compared to non-GnRH hypothalamic cells, which is about 50 fold higher for miR200/429 (Fig. 3E) than for miR-155 (Fig. S11A), Cebpb mRNA levels were significantly increased in non-GnRH cells of the preoptic region after TSB-155 infusion (Fig. S11B), while TSB-200 treatment altered neither Cebpb nor Zeb1 transcripts in these cells (Fig. S11B, S11C). Altogether, these data suggest that, in keeping with the complex feedback mechanisms at work (Fig. 7), selectively applying the brakes to $\mathrm{GnRH}$ production in an excessive manner (Fig. 4F, 4G) and then releasing them prematurely can trigger precocious puberty, possibly due to a rebound effect. To determine whether the miR-200/Zeb1 network could control GnRH function outside of this critical infantile time window leading up to puberty, we infused TSB-200 into the hypothalamic preoptic region of cycling adult female mice and followed their estrous cycles (Fig. 6C). While control mice infused with scrambled sequences did not exhibit any marked 
alteration of their estrous cycles, most mice treated with TSB-200 (5 out of 6 ) showed a slight prolongation in the number of days spent in diestrus (a basal stage when $\mathrm{LH}$ is released at nadir levels) and eventually reached proestrus (when the preovulatory surge of LH occurs), but displayed an incomplete cycle at least once during the first two weeks after injection (Fig. 6C). In line with this observation, $\mathrm{LH}$ levels measured during proestrus one week after injection showed a characteristic surge in control animals but not in TSB-200-treated mice (Fig. 6D; $F(2,14)=4.371, p=0.0335, n=5-6$ per group; TSB-200 $>1$ week, $p=0.0262$; TSB$200>2$ weeks, $p=0.6976$ ). In 4 of the 6 animals treated with TSB-200, LH levels recovered and displayed normal preovulatory surges by the third week after TSB infusion (Fig. 6D).

\section{Discussion}

The balance between inductive and repressive signals is a process essential for successful reproduction, not only in animals but in living organisms in general ${ }^{41,42}$. Our data provide the first physiological and neuroanatomical evidence that miRNAs, which have been shown to regulate somatic growth, including the development of peripheral sexual organs ${ }^{14-16}$, also play an essential role in the postnatal development of the hypothalamic neuroendocrine neurons controlling the onset of puberty and fertility in mammals, by modulating this balance in the GnRH gene network. During this infantile "critical period" lasting just a few days, when the first centrally-driven gonad-independent activation of the hypothalamic-pituitary-gonadal axis occurs, setting in motion, for example, the growth of the first wave of ovarian follicles that will ovulate at puberty in females and the development of the testes in males (see for review ${ }^{43}$ ), our findings show that a switch in miRNA expression in turn flips a switch in a multilayered array of $\mathrm{GnRH}$ gene activators and repressors, permitting the sustained increase of the neurohormone required for normal sexual maturation. Interfering with the binding and functional effects of two key miRNA species, miR-200/429, which is not only upregulated during this critical period but selectively enhanced in GnRH neurons, and miR155, which appears to act on other hypothalamic cell types as well, and mediates, for example, the effects of a concomitant release of $\mathrm{NO}$ upstream of $\mathrm{GnRH}$ neurons, blunts this 
infantile increase in GnRH expression. In addition, this in vivo alteration of the miR-200/429transcription factor micro-network leads to the disruption of normal puberty onset as well as normal estrous cyclicity in adulthood.

The fact that $\mathrm{GnRH}$ neurons form an extremely small population ( $>00$ neurons in a mouse brain) and their scattered distribution in a continuum from the olfactory bulb to the hypothalamus, albeit with a strong concentration in the hypothalamic preoptic area, have made genetic and epigenetic studies in these neurons a veritable technical challenge until now. Our successful separation of $\mathrm{GnRH}$ from non-GnRH cells in the preoptic region of $G n R H:: G f p$ mice has allowed us to determine miRNA expression profiles specific to this very limited population of neurons in the postnatal brain, i.e. once the processes of differentiation and the establishment of connectivity, including their projection over several millimeters to the hypothalamic median eminence, are complete. The difficulty of this approach is evident from the fact that other such studies, even those focusing on more abundant neuronal types, have not always succeeded ${ }^{44}$. Using this approach, we were not only able to study changes in miRNA expression in $\mathrm{GnRH}$ neurons at different stages of postnatal development, but even to analyze the effects of the selective invalidation of miRNA biogenesis and the acute manipulation of specific miRNA networks on the expression of transcription factors, $\mathrm{GnRH}$ promoter activity and $\mathrm{GnRH}$ expression in the postnatal brain in vivo.

Our findings show that miRNA processing in $\mathrm{GnRH}$ neurons is required to promote sexual development, but surprisingly, not $\mathrm{GnRH}$ neuronal migration in vivo. The specific role of miRNAs in sustaining the expression of GnRH is shown in Gnrh::Cre; DiceroxP/loxP mice, in which $\mathrm{GnRH}$ expression appears to be normal during the perinatal and the early infantile periods, and the process of sexual maturation commences normally and leads to vaginal opening in $80 \%$ of the individuals. However, these mice never achieve puberty because of the progressive decrease in GnRH promoter activity from the second week of postnatal life and its complete extinction during the juvenile period. Our data indicate that miRNA species whose expression is upregulated in $\mathrm{GnRH}$ neurons during this critical period of 7 to 12 days of age include miR-155 and members of the miR-200 family. Notably, the striking enrichment 
of miR-200 family members during this period is restricted to $\mathrm{GnRH}$ neurons, indicating a highly specific function for these miRNA species in the regulation of $\mathrm{GnRH}$ expression. We have identified several genes targeted directly or indirectly by miR-155 and miR-200/429, whose repression (e.g. Cebpb and Zeb1) or activation (e.g. Pou2f1 or Meis1, which are both targets for Zeb1) is required for normal GnRH expression at 12 days of age. In particular miR-200/429 and its target Zeb1, which can directly repress the GnRH promoter, also seem to form a double-negative loop with the key $\mathrm{GnRH}$ promoter activator Pou2f1, while miR-155 counteracts NO/Cebpb-dependent $\mathrm{GnRH}$ repression. Nor can we rule out the possibility that some molecules act as both activators and repressors depending upon physiological conditions and cellular context, as we have seen in the case of Cebpb, a GnRH promoter repressor that nevertheless increases Zeb1 levels in $\mathrm{GnRH}$ neurons but not in non-GnRH hypothalamic cells (which do not express miR-200/429), or that some of these promoter modulators could exert a reciprocal regulatory effect on the miRNAs that control their expression, as is the case with Zeb1 and miR-200/429 ${ }^{24}$.

Surprisingly, the pattern of expression of various known GnRH promoter modulators is not the same at P12. While activators that are upregulated specifically in $\mathrm{GnRH}$ neurons in wildtype mice at P12 show reduced expression with the blockade of miR-200/429 binding (with the exception of DIx5, which has no Zeb1 binding site and is thus probably regulated by other miRNA-effector pathways), the expression of one putative activator, Dlx1, is increased. Apart from a possible indirect effect, the fact that unlike Pou2f1 or Meis1, the expression of DIx1 shows a downward trend in wild-type $\mathrm{GnRH}$ neurons at P12 could explain this seemingly paradoxical finding. The lack of effect of a miRNA-200/429 blockade on the expression of $\mathrm{GnRH}$ activator genes that contain no or few Zeb1-binding sites and that are not differentially expressed during the infantile-juvenile transition in $\mathrm{GnRH}$ neurons (but that could nevertheless play a role in baseline $\mathrm{GnRH}$ production or its regulation in other physiological contexts) further highlights the importance of the miR-200/Zeb1/Cebpb switch in the prepubertal increase in $\mathrm{GnRH}$ expression. Our findings show, in addition, that both miR-155 (by interfering with NO/Cebpb-mediated signaling by nNOS neurons, themselves activated 
by Kisspeptin ${ }^{36}$ ) and miR-200/429 (through Zeb1) could also play a role in the intricate relationship between different cells of the hypothalamic $\mathrm{GnRH}$ network by affecting the expression of the Kisspeptin receptor Gpr54, and thus modulating the Kisspeptin-Gpr54mediated activation of $\mathrm{GnRH}$ expression. NO itself, by being both essential for the initiation of puberty ${ }^{37}$ and participating in the repression of $\mathrm{GnRH}$ expression ${ }^{22}$, could play a more complex role than suspected hithertofore. The Kisspetin/nNOS/GnRH neuronal microcircuit and miRNA-gene network in $\mathrm{GnRH}$ neurons (Figure 7) would be ideally poised to ignite rhythmic $\mathrm{GnRH}$ gene transcription, which has recently been associated to pulsatile $\mathrm{GnRH}$ secretion ${ }^{45,46}$ in response to developmental and bodily cues during the infantile period in mice ${ }^{43}$, a developmental stage highly reminiscent of minipuberty in humans ${ }^{47}$.

Other feedback loops, possibly involving the expression of miR-155 in other cell types, could also exist, as suggested by the fact that simultaneously neutralizing both miR-200/429 binding to Zeb1 and miR-155 binding to Cebpb results in a considerably less striking effect on peripubertal LH levels than the blockade of miR-200/429 alone. Intriguingly, while blocking the binding of miR-200/429 to Zeb1 during this infantile-juvenile critical period dramatically reduces $\mathrm{GnRH}$ promoter activity at the cellular level, these animals go on to display precocious, not delayed, puberty. This counterintuitive finding could stem from a rebound effect, where the prolonged inhibition of $\mathrm{GnRH}$ expression (TSBs, once injected, remain at the injection site for around 2 weeks) results in a compensatory spike once the inhibition is relieved. Such a phenomenon has been demonstrated previously in human populations, where children whose $\mathrm{GnRH}$ system is blunted due to exposure to endocrine disruptors of agricultural origin undergo precocious puberty when they migrate to countries that do not use them ${ }^{48}$.

To conclude, our data are the first to indicate not only that miRNAs are active in the hypothalamic GnRH network, but that miRNA-200/429 and miRNA-155 are key components of a complex developmental switch that controls the activity of the $\mathrm{GnRH}$ promoter, as illustrated in the models presented in Figure 7 and Figure S12, and whose correct functioning is essential for the normal initiation of puberty and reproductive success in adulthood. 
Moreover, this dramatic switch in gene expression appears to involve a multilayered and interconnected array of miRNAs and their target genes in GnRH neurons, with its own inbuilt feedback control mechanism, that alters the balance between inductive and repressive signals during the infantile critical period and thus leads to increased $\mathrm{GnRH}$ production. Deciphering the mechanisms through which miRNAs contribute to precocious or delayed puberty through their actions on the functioning of the $\mathrm{GnRH}$ neural network may thus not only provide novel insights into the epigenetic regulation of maturational processes, fascinating in itself, but pave the way to a better understanding of idiopathic infertility ${ }^{49,50}$ and the elaboration of new diagnostic and therapeutic options in humans.

\section{Materials and Methods}

\section{Animals}

All C57BI/6J mice were housed under specific pathogen-free conditions in a temperaturecontrolled room $\left(21-22^{\circ} \mathrm{C}\right)$ with a $12 \mathrm{~h}$ light/dark cycle and ad libitum access to food and water. Gnrh::Cre (Tg(Gnrh1::Cre)1Dlc), Dicer LoxP/LoxP, and Gnrh::Gfp mice were a generous gift of Dr. Catherine Dulac (Howard Hughes Medical Institute, Cambridge MA) ${ }^{18}$, Dr. Brian Harfe (University of Florida, FL) ${ }^{12}$ and Dr. Daniel J. Spergel (Section of Endocrinology, Department of Medicine, University of Chicago, IL) ${ }^{51}$, respectively. tdTomato ${ }^{\text {loxP/STOP }}$ mice (B6.Cg-Gt(ROSA)26Sortm9(CAG-tdTomato)Hze/J) were purchased from the Jackson laboratory (Maine, USA). Mice were genotyped by PCR using primers listed in table S3. Animal studies were approved by the Institutional Ethics Committees for the Care and Use of Experimental Animals of the Universities of Lille and Cordoba; all experiments were performed in accordance with the guidelines for animal use specified by the European Union Council Directive of September 22, 2010 (2010/63/EU).

\section{Physiological measurements}


Fertility index. Male and female fertility indices were calculated from the number of litters per females during a 120-day-long mating.

Puberty onset. Weaned female mice were checked daily for vaginal opening. After vaginal opening, vaginal smears were performed daily and analyzed under an inverted microscope to identify the specific day of the estrous cycle. Weaned males were checked daily for balanopreputial separation.

Hormone level measurements. Protocols and doses for in vivo testing of the $\mathrm{LH}$ response to $\mathrm{GnRH}$, kisspeptin-10 and NMDA were as described in detail elsewhere ${ }^{52}$. Serum LH and FSH levels were measured using radioimmunoassay kits supplied by the National Institutes of Health (Dr. A. F. Parlow, National Hormone and Peptide Program, Torrance, CA). Rat LH$\mathrm{I}-10$ and $\mathrm{FSH}-\mathrm{I}-9$ were labeled with ${ }^{125} \mathrm{I}$ using lodo-gen tubes, following the instructions of the manufacturer (Pierce, Rockford, IL). Hormone concentrations were determined using reference preparations of LH-RP-3 and FSH-RP-2 as standards. Intra- and inter-assay coefficients of variation were $<8$ and $10 \%$ for $\mathrm{LH}$ and $<6$ and $9 \%$ for $\mathrm{FSH}$, respectively. The sensitivity of the assay was $3.75 \mathrm{pg} / \mathrm{tube}$ for $\mathrm{LH}$ and $20 \mathrm{pg} / \mathrm{tube}$ for $\mathrm{FSH}$. The accuracy of hormone measurements was confirmed by the assessment of rodent serum samples of known concentration (external controls).

\section{Ovarian histology and quantitative analysis}

Ovaries and testes were collected from 3-month-old Dicer ${ }^{\text {LoxP/LoxP }}$ and Gnrh::Cre; Dicer LoxP/LoxP mice, immersion-fixed in $4 \%$ PFA solution and stored at $4^{\circ} \mathrm{C}$. Paraffin-embedded ovaries and testes were sectioned at a thickness of $5 \mu \mathrm{m}$ (histology facility, University of Lille 2, France) and stained with hematoxylin-eosin.

\section{Tissue preparation}

For immunohistochemical analysis, embryos were obtained after cervical dislocation from timed-pregnant Gnrh::Cre; Dicer ${ }^{\text {LxP/+ }}$ crossed with Gnrh::Cre; Dicer ${ }^{\text {LxP/LoxP }}$ male mice. Embryos were washed thoroughly in cold $0.1 \mathrm{~m}$ PBS, fixed in fixative solution [4\% 
paraformaldehyde (PFA), $0.2 \%$ picric acid in $0.1 \mathrm{~m} \mathrm{PBS}, \mathrm{pH} 7.4]$ for $6-8 \mathrm{~h}$ at $4^{\circ} \mathrm{C}$ and cryoprotected in $20 \%$ sucrose overnight at $4^{\circ} \mathrm{C}$. The following day, embryos were embedded in OCT embedding medium (Tissue-Tek), frozen on dry ice, and stored at $-80^{\circ} \mathrm{C}$ until sectioning. Postnatal (P0 to P28) and adult mice (3-5 months old) were anesthetized with $50-100 \mathrm{mg} / \mathrm{kg}$ of Ketamine- $\mathrm{HCl}$ and $5-10 \mathrm{mg} / \mathrm{kg}$ Xylazine- $\mathrm{HCl}$ and perfused transcardially with $2-10 \mathrm{ml}$ of saline, followed by $10-100 \mathrm{ml}$ of $4 \%$ PFA, pH7.4. Brains were collected, postfixed in the same fixative for $2 \mathrm{~h}$ at $4^{\circ} \mathrm{C}$, embedded in OCT embedding medium (Tissue-Tek), frozen on dry ice, and stored at $-80^{\circ} \mathrm{C}$ until cryosectioning.

\section{Immunohistochemistry}

Tissues were cryosectioned (Leica cryostat) at $16 \mu \mathrm{m}$ for embryos and pre-weaning postnatal mice, and at $35 \mu \mathrm{m}$ (free-floating sections) for post-weaning and adult brains. Immunohistochemistry was performed as previously reported ${ }^{53,54}$, using Alexa-Fluor 488 $(1: 400)$ and Cy3-conjugated (1:800) secondary antibodies (Invitrogen). Fluorescent specimens were mounted using 1,4-diazabicyclo[2.2.2]octane (Sigma-Aldrich). The primary antisera used were as follows: rabbit anti-GnRH (1:3000), a generous gift from Prof. G. Tramu (Centre Nationale de la Recherche Scientifique, URA 339, Université Bordeaux I, Talence, France) ${ }^{55}$.

\section{Isolation of hypothalamic GnRH neurons using Fluorescence-Activated Cell Sorting}

The preoptic regions of Gnrh::Gfp; Dicer ${ }^{\text {LoxP/LoxP }}$ and Gnrh::Gfp; Gnrh::Cre; Dicer ${ }^{\text {LoxP/LoxP }}$ mice were microdissected and enzymatically dissociated using a Papain Dissociation System (Worthington, Lakewood, NJ) to obtain single-cell suspensions. FACS was performed using an EPICS ALTRA Cell Sorter Cytometer device (BD Bioscience). The sort decision was based on measurements of GFP fluorescence (excitation: $488 \mathrm{~nm}, 50 \mathrm{~mW}$; detection: GFP bandpass $530 / 30 \mathrm{~nm}$, autofluorescence bandpass $695 / 40 \mathrm{~nm}$ ) by comparing cell suspensions from Gnrh::Gfp and wild-type animals, as indicated in figure S5. For each animal, 400 to 800 
GFP-positive cells were sorted directly into $10 \mu$ l extraction buffer: $0.1 \%$ Triton $₫ X-100$

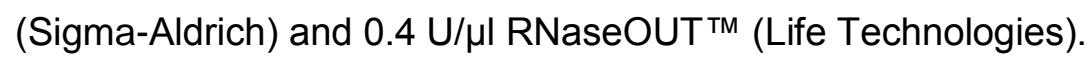

\section{Quantitative RT-PCR analyses}

For gene expression analyses, mRNAs obtained from FACS-sorted GnRH neurons were reverse transcribed using SuperScript ${ }^{\circledR}$ III Reverse Transcriptase (Life Technologies) and a linear preamplification step was performed using the TaqMan® PreAmp Master Mix Kit protocol (P/N 4366128, Applied Biosystems). Real-time PCR was carried out on Applied Biosystems 7900HT Fast Real-Time PCR System using exon-boundary-specific TaqMan® Gene Expression Assays (Applied Biosystems): Aes (Aes-Mm00507847_m1), Cebpb (Cebpb-Mm00843434_s1), DIx1(DIx1-Mm00438424_m1), DIx5 (Dlx5-Mm00438430_m1), Gfp (Gfp-Mr03989638_mr), Gnrh1 (Gnrh1-Mm01315605_m1), Gpr54 (Gpr54Mm00475046_m1), Lpin1 ((Lpin1-Mm00550511_m1), Maf (Maf-Mm02581355_s1), Meis1 (Meis1-Mm00487664_m1), Msx1 (Msx1-Mm00440330_m1), Otx2 (Otx2-Mm00446859_m1), Pbx1 (Pbx1-Mm04207617_m1), Pknox1 (Pknox1-Mm00479320_m1), Pou2f1 (Pou2f1Mm00448332_m1), Tle4 (Tle4-Mm01195172_m1), Zeb1 (Zeb1-Mm00495564_m1). Control housekeeping genes: r18S (18S-Hs99999901_s1); ACTB (Actb-Mm00607939_s1).

MicroRNA expression analyses were performed using stem-loop RT-PCR based TaqMan Rodent MicroRNA Arrays (Applied Biosystems). Briefly, miRNAs obtained from FACS-sorted GnRH neurons were reverse transcribed using the TaqMan miRNA Reverse Transcription Kit (Applied Biosystems) in combination with the stem-loop Megaplex primer pool sets A and B according to the manufacturer's instructions. A linear preamplification step was performed using the TaqMan® PreAmp Master Mix Kit protocol (P/N 4366128, Applied Biosystems) and quantitative real-time PCR were performed using TaqMan Low-Density Arrays (Applied Biosystems) on an Applied Biosystems 7900HT thermocycler using the manufacturer's recommended cycling conditions.

Gene and miRNA expression data were analyzed using SDS 2.4.1 and Data Assist 3.0.1 software (Applied Biosystems). 
Zeb1 chromatin immunoprecipitation (ChIP) assays

Immortalized GnRH neurons (GN11 cells) were cultured in DMEM + 10\% FBS (Life Technology). Prior to experimental assays, cells were washed twice in PBS and incubated overnight in serum-free medium. The next morning, 10\% FBS was added for $2 \mathrm{~h}$. Chromatin isolation was performed using the ChIP-IT Express kit (Active Motif) following the manufacturer's instructions. After DNA shearing by sonication ( 9 min total, 20 s pulses at $70 \%$ power followed by a 40s pause; on ice), protein-bound DNA was immunoprecipitated at $4^{\circ} \mathrm{C}$ overnight using $5 \mu \mathrm{g}$ of a polyclonal goat anti-rabbit Zeb1 antibody (E20; Santa Cruz Biotechnology; SC-10572) or control goat IgGs (Santa Cruz Biotechnology; sc-2028). ChIPDNA fragments were purified using a QIAquick PCR purification kit (Qiagen), and analyzed by qPCR on a CFX96 thermal cycler (Biorad) using GoTaq® qPCR Master Mix (Promega) and the primers indicated in Table S4.

\section{Western blot analyses}

The preoptic area of the hypothalamus was dissected from each animal using Wecker scissors (Moria, France) under a binocular magnifying glass, and protein extracted in $200 \mu \mathrm{l}$ of lysis buffer (25 mM Tris, pH 7.4, $\beta$-glycerophosphate, 1.5 mM EGTA, 0.5 mM EDTA, 1 mM sodium pyrophosphate, $1 \mathrm{mM}$ sodium orthovanadate, $10 \mu \mathrm{g} / \mathrm{ml}$ leupeptin and pepstatin $\mathrm{A}, 10$ $\mu \mathrm{g} / \mathrm{ml}$ apoprotinin, $100 \mu \mathrm{g} / \mathrm{ml} \mathrm{PMSF}$, and $1 \%$ Triton-X100) by trituration of the fragments through 22 and 26 gauge needles in succession. Tissue lysates were cleared by centrifugation at $14000 \mathrm{rpm}$ for $15 \mathrm{~min}$ at $4^{\circ} \mathrm{C}$. Protein content was determined using the Bradford method (Bio-Rad, Hercules, CA) and equal amounts of protein were mixed with $4 \mathrm{X}$ sample buffer (Invitrogen). Samples were boiled for $5 \mathrm{~min}$ and stored at $-80^{\circ} \mathrm{C}$ until use. Samples were reboiled for $5 \mathrm{~min}$ after thawing and electrophoresed for $75 \mathrm{~min}$ at $150 \mathrm{~V}$ in $7 \%$ Tris-acetate, or for $50 \mathrm{~min}$ at $200 \mathrm{~V}$ in precast $4-12 \%$ MES SDS-polyacrylamide gels according to the protocol supplied with the NuPAGE system (Invitrogen). After size fractionation, the proteins were transferred onto $0.2 \mu \mathrm{m}$ pore-size polyvinylidene difluoride 
membranes (LC2002; Invitrogen) in the blot module of the NuPAGE system (Invitrogen) for $75 \mathrm{~min}$ at room temperature. Membranes were blocked for $1 \mathrm{~h}$ in blocking buffer [TBS with 0.05\% Tween 20 (TBST) and 5\% nonfat milk] at room temperature, and incubated overnight at $4^{\circ} \mathrm{C}$ with the appropriate primary antibody diluted in blocking buffer (rabbit polyclonal antiRFP, 600-401-379, 1:1000, Rockland antibodies \& assays; rabbit polyclonal anti-nNOS, sc8309, 1:500, Santa Cruz technologies; rabbit polyclonal anti-Ser ${ }^{1412}$ phospho-nNOS, PA1032; 1:1000, Affinity BioReagents; goat polyclonal anti-actin, sc-1616, 1:1000). Membranes were washed four times with TBST the following day before being exposed to HRPconjugated secondary antibodies diluted in blocking buffer for $1 \mathrm{~h}$ at room temperature. Immunoreactions were visualized using the ECL detection kit (NEL101; PerkinEImer, Boston, MA). Immunoblots were scanned using a desktop scanner (Epson Expression 1680 PRO) and Adobe Photoshop, and band intensities were determined using ImageJ software $(\mathrm{NIH}$, Bethesda).

\section{Target site blockers (TSBs)}

To selectively hamper the silencing activity of miR-155 and miR-200b/200c/429 on Cebpb and Zeb1 respectively in vivo, we used custom-designed target sites blockers with phosphorothioate backbone modifications from Exiqon (miRCURY LNA ${ }^{\mathrm{TM}}$ microRNA Target Site Blockers, in vivo ready). TSB sequences are designed with a large arm that covers the miRNA binding site and a short arm outside the miRNA seed to ensure target specificity. In detail, one sequence was generated to protect the unique miR-155-binding site in the Cebpb 3'UTR (TSB-155, Fig. S7). Five sequences were generated to protect the five different miR200b/200c/429-binding sites in the Zeb1 3'UTR (Fig. S7) and mixed at equimolar ratios (TSB-200).

\section{Stereotactic brain infusions of TSBs}

Gnrh::Gfp mice were placed in a stereotaxic frame (Kopf® Instruments, California) under anesthesia (isoflurane), and a burr hole was drilled $1 \mathrm{~mm}$ lateral to the bregma, according to 
a mouse brain atlas (Paxinos and Franklin, 2004). A $10 \mu \mathrm{l} \mathrm{Hamilton}$ syringe was slowly inserted into the bottom of the left lateral ventricle $(3.5 \mathrm{~mm}$ deep relative to the dura), and $1 \mu \mathrm{l}$ of the different treatment solutions (TSB-200, $50 \mu \mathrm{M}, \mathrm{n}=6$; TSB-155, $50 \mu \mathrm{M}, \mathrm{n}=6$ ) or vehicle (PBS, pH7.4, $\mathrm{n}=6$ ) was injected using an infusion pump (KD Scientific, Holliston, MA) over 4 min. Animals were subjected to intracranial surgery at P9 and killed at P12.

\section{Identification of putative Zeb1-binding sites}

To identify putative Zeb1- and C/EBP $\beta$-binding sites in the promoter regions of target genes, $1.5 \mathrm{~Kb}$ of the genomic sequence upstream of the transcription initiation site of $\mathrm{GnRH}$, Gpr54 and the GnRH promoter activators under study, were analyzed using ALGEN PROMO 3.0 software (http://alggen.Isi.upc.es/cgi-bin/promo v3/promo/promoinit.cgi?dirDB=TF 8.3) and jaspar database (http://jaspar.genereg.net/).

\section{Statistics}

All analyses were performed using Prism 5 (GraphPad Software) and assessed for normality (Shapiro-Wilk test) and variance, when appropriate. Sample sizes were chosen according to standard practice in the field. Data were compared using an unpaired two-tailed Student's $t$ test, a one-way ANOVA for multiple comparisons or a two-way repeated-measures ANOVA. A Tukey's post hoc test was performed when appropriate. The significance level was set at $p$ $<0.05$. Data are indicated as means \pm SEM. The number of biologically independent experiments, $p$ values and degrees of freedom are indicated either in the main text or in the figure legends.

\section{Acknowledgments}

The supplemental information includes 11 figures and 3 tables.

This research was supported by the Fondation pour la Recherche Médicale (FRM, Equipe FRM 2005 and DEQ20130326524, France to V.P.), grant BFI2011-025021 from the Spanish Ministry of Economy and Science (to M.T.-S.) and the ERC COST action BM1015 (to V.P, P.G. and M.T.-S.). A.M. was a postdoctoral fellow supported by the FRM. We are indebted to 
Dr. Domenico Accili (University of Columbia) for his precious help in conducting the ChIP assays. We thank M. Tardivel (Imaging University core facility), Marie-Hélène Gevaert (Histology University core Facility), D. Taillieu and J. Devassine (Animal facility, Inserm and University of Lille) for expert technical assistance.

\section{References}

1. Ojeda, S.R. \& Lomniczi, A. Puberty in 2013: Unravelling the mystery of puberty. Nat Rev Endocrinol 10, 67-69 (2014).

2. Schwanzel-Fukuda, M., Bick, D. \& Pfaff, D.W. Luteinizing hormone-releasing hormone (LHRH)-expressing cells do not migrate normally in an inherited hypogonadal (Kallmann) syndrome. Brain Res Mol Brain Res 6, 311-326 (1989).

3. Mason, A.J., et al. A deletion truncating the gonadotropin-releasing hormone gene is responsible for hypogonadism in the hpg mouse. Science 234, 1366-1371 (1986).

4. de Roux, N., et al. A family with hypogonadotropic hypogonadism and mutations in the gonadotropin-releasing hormone receptor. $N$ Engl J Med 337, 1597-1602 (1997).

5. de Roux, N., et al. Hypogonadotropic hypogonadism due to loss of function of the KiSS1derived peptide receptor GPR54. Proc.Natl.Acad.Sci.U.S.A 100, 10972-10976 (2003).

6. Ma, Y.J., Junier, M.P., Costa, M.E. \& Ojeda, S.R. Transforming growth factor-alpha gene expression in the hypothalamus is developmentally regulated and linked to sexual maturation. Neuron 9, 657-670 (1992).

7. Prevot, $V_{\text {., }}$ et al. Normal female sexual development requires neuregulin-erbB receptor signaling in hypothalamic astrocytes. J.Neurosci. 23, 230-239 (2003).

8. Seminara, S.B., et al. The GPR54 gene as a regulator of puberty. N.Engl.J.Med. 349, 16141627 (2003).

9. Urbanski, H.F. \& Ojeda, S.R. A role for N-methyl-D-aspartate (NMDA) receptors in the control of LH secretion and initiation of female puberty. Endocrinology 126, 1774-1776 (1990).

10. Davis, T.H., et al. Conditional loss of Dicer disrupts cellular and tissue morphogenesis in the cortex and hippocampus. J Neurosci 28, $4322-4330$ (2008).

11. Dugas, J.C., et al. Dicer1 and miR-219 Are required for normal oligodendrocyte differentiation and myelination. Neuron 65, 597-611 (2010).

12. Harfe, B.D., McManus, M.T., Mansfield, J.H., Hornstein, E. \& Tabin, C.J. The RNaseIII enzyme Dicer is required for morphogenesis but not patterning of the vertebrate limb. Proc Natl Acad Sci U S A 102, 10898-10903 (2005).

13. Lynn, F.C., et al. MicroRNA expression is required for pancreatic islet cell genesis in the mouse. Diabetes 56, 2938-2945 (2007).

14. Hasuwa, H., Ueda, J., Ikawa, M. \& Okabe, M. miR-200b and miR-429 function in mouse ovulation and are essential for female fertility. Science 341, 71-73 (2013).

15. Luense, L.J., Carletti, M.Z. \& Christenson, L.K. Role of Dicer in female fertility. Trends Endocrinol Metab 20, 265-272 (2009).

16. Papaioannou, M.D. \& Nef, S. microRNAs in the testis: building up male fertility. J Androl 31, 26-33 (2010).

17. Bernstein, E., Caudy, A.A., Hammond, S.M. \& Hannon, G.J. Role for a bidentate ribonuclease in the initiation step of RNA interference. Nature 409, 363-366 (2001).

18. Yoon, H., Enquist, L.W. \& Dulac, C. Olfactory inputs to hypothalamic neurons controlling reproduction and fertility. Cell 123, 669-682 (2005).

19. d'Anglemont de Tassigny, X., Ackroyd, K.J., Chatzidaki, E.E. \& Colledge, W.H. Kisspeptin signaling is required for peripheral but not central stimulation of gonadotropin-releasing hormone neurons by NMDA. J Neurosci 30, 8581-8590 (2010). 
20. Wierman, M.E., Kiseljak-Vassiliades, K. \& Tobet, S. Gonadotropin-releasing hormone (GnRH) neuron migration: Initiation, maintenance and cessation as critical steps to ensure normal reproductive function. Front Neuroendocrinol 32, 43-52 (2011).

21. Forni, P.E. \& Wray, S. GnRH, anosmia and hypogonadotropic hypogonadism - where are we? Front Neuroendocrinol, 165-177 (2015).

22. Belsham, D.D. \& Mellon, P.L. Transcription factors Oct-1 and C/EBPbeta (CCAAT/enhancer-binding protein-beta) are involved in the glutamate/nitric oxide/cyclic-guanosine 5'-monophosphate-mediated repression of mediated repression of gonadotropin-releasing hormone gene expression. Mol Endocrinol 14, 212-228 (2000).

23. Lee, V.H., Lee, L.T. \& Chow, B.K. Gonadotropin-releasing hormone: regulation of the GnRH gene. FEBS J 275, 5458-5478 (2008).

24. Burk, U., et al. A reciprocal repression between ZEB1 and members of the miR-200 family promotes EMT and invasion in cancer cells. EMBO Rep 9, 582-589 (2008).

25. Le Bechec, A., et al. MIR@NT@N: a framework integrating transcription factors, microRNAs and their targets to identify sub-network motifs in a meta-regulation network model. BMC Bioinformatics 12, 67 (2011).

26. Alisi, A., et al. Mirnome analysis reveals novel molecular determinants in the pathogenesis of diet-induced nonalcoholic fatty liver disease. Lab Invest 91, 283-293 (2011).

27. Klein, D., et al. MicroRNA expression in alpha and beta cells of human pancreatic islets. PLoS One 8, e55064 (2013).

28. Dweep, H., Sticht, C., Pandey, P. \& Gretz, N. miRWalk--database: prediction of possible miRNA binding sites by "walking" the genes of three genomes. J Biomed Inform 44, 839847 (2011).

29. Costinean, S., et al. Src homology 2 domain-containing inositol-5-phosphatase and CCAAT enhancer-binding protein beta are targeted by miR-155 in B cells of Emicro-MiR155 transgenic mice. Blood 114, 1374-1382 (2009).

30. Koch, M., Mollenkopf, H.J., Klemm, U. \& Meyer, T.F. Induction of microRNA-155 is TLRand type IV secretion system-dependent in macrophages and inhibits DNA-damage induced apoptosis. Proc Natl Acad Sci U S A 109, E1153-1162 (2012).

31. Rodriguez, A., et al. Requirement of bic/microRNA-155 for normal immune function. Science 316, 608-611 (2007).

32. Yang, J.H., Li, J.H., Jiang, S., Zhou, H. \& Qu, L.H. ChIPBase: a database for decoding the transcriptional regulation of long non-coding RNA and microRNA genes from ChIP-Seq data. Nucleic Acids Res 41, D177-187 (2013).

33. Heinz, S., et al. Simple combinations of lineage-determining transcription factors prime cis-regulatory elements required for macrophage and B cell identities. Mol Cell 38, 576589 (2010).

34. Lefterova, M.I., et al. Cell-specific determinants of peroxisome proliferator-activated receptor gamma function in adipocytes and macrophages. Mol Cell Biol 30, 2078-2089 (2010).

35. Novaira, H.J., Fadoju, D., Diaczok, D. \& Radovick, S. Genetic mechanisms mediating kisspeptin regulation of GnRH gene expression. J Neurosci 32, 17391-17400 (2012).

36. Hanchate, N.K., et al. Kisspeptin-GPR54 Signaling in Mouse NO-Synthesizing Neurons Participates in the Hypothalamic Control of Ovulation. J Neurosci 32, 932-945 (2012).

37. Bellefontaine, N., et al. Leptin-dependent neuronal NO signaling in the preoptic hypothalamus facilitates reproduction. J Clin Invest 124, 2550-2559 (2014).

38. Bouret, S.G., Draper, S.J. \& Simerly, R.B. Formation of projection pathways from the arcuate nucleus of the hypothalamus to hypothalamic regions implicated in the neural control of feeding behavior in mice. J.Neurosci. 24, 2797-2805 (2004).

39. Caron, E., Ciofi, P., Prevot, V. \& Bouret, S.G. Alteration in neonatal nutrition causes perturbations in hypothalamic neural circuits controlling reproductive function. $J$ Neurosci 32, 11486-11494 (2012). 
40. Rameau, G.A., et al. Biphasic coupling of neuronal nitric oxide synthase phosphorylation to the NMDA receptor regulates AMPA receptor trafficking and neuronal cell death. $J$ Neurosci 27, 3445-3455 (2007).

41. Lee, J.H., et al. Regulation of temperature-responsive flowering by MADS-box transcription factor repressors. Science 342, 628-632 (2013).

42. Lomniczi, A., et al. Epigenetic control of female puberty. Nat Neurosci 16, 281-289 (2013).

43. Prevot, V. Puberty in mice and rats. in Knobil and Neill's Physiology of Reproduction (eds. Plant, T.M. \& Zeleznik, J.) pp 1395-1439 (Elsevier, New York, 2015).

44. Issler, O., et al. MicroRNA 135 is essential for chronic stress resiliency, antidepressant efficacy, and intact serotonergic activity. Neuron 83, 344-360 (2014).

45. Choe, H.K., et al. Real-Time GnRH Gene Transcription in GnRH Promoter-Driven Luciferase-Expressing Transgenic Mice: Effect of Kisspeptin. Neuroendocrinology (2015).

46. Choe, H.K., et al. Synchronous activation of gonadotropin-releasing hormone gene transcription and secretion by pulsatile kisspeptin stimulation. Proc Natl Acad Sci U S A 110, 5677-5682 (2013).

47. Kuiri-Hanninen, T., Sankilampi, U. \& Dunkel, L. Activation of the hypothalamic-pituitarygonadal axis in infancy: minipuberty. Horm Res Paediatr 82, 73-80 (2014).

48. Parent, A.S., et al. The timing of normal puberty and the age limits of sexual precocity: variations around the world, secular trends, and changes after migration. Endocr Rev 24, 668-693 (2003).

49. Pitteloud, N., Durrani, S., Raivio, T. \& Sykiotis, G.P. Complex genetics in idiopathic hypogonadotropic hypogonadism. Front Horm Res 39, 142-153 (2010).

50. Topaloglu, A.K. \& Kotan, L.D. Molecular causes of hypogonadotropic hypogonadism. Curr Opin Obstet Gynecol 22, 264-270 (2010).

51. Spergel, D.J., Kruth, U., Hanley, D.F., Sprengel, R. \& Seeburg, P.H. GABA- and glutamateactivated channels in green fluorescent protein-tagged gonadotropin-releasing hormone neurons in transgenic mice. J.Neurosci. 19, 2037-2050 (1999).

52. Garcia-Galiano, D., et al. Kisspeptin signaling is indispensable for neurokinin B, but not glutamate, stimulation of gonadotropin secretion in mice. Endocrinology 153, 316-328 (2012).

53. Hanchate, N.K., et al. SEMA3A, a Gene Involved in Axonal Pathfinding, Is Mutated in Patients with Kallmann Syndrome. PLoS Genet 8, e1002896 (2012).

54. Messina, A., et al. Dysregulation of Semaphorin7A/beta1-integrin signaling leads to defective GnRH-1 cell migration, abnormal gonadal development and altered fertility. Hum Mol Genet 20, 4759-4774 (2011).

55. Beauvillain, J.C. \& Tramu, G. Immunocytochemical demonstration of LH-RH, somatostatin, and ACTH-like peptide in osmium-postfixed, resin-embedded median eminence. J.Histochem.Cytochem. 28, 1014-1017 (1980). 
Figures

A

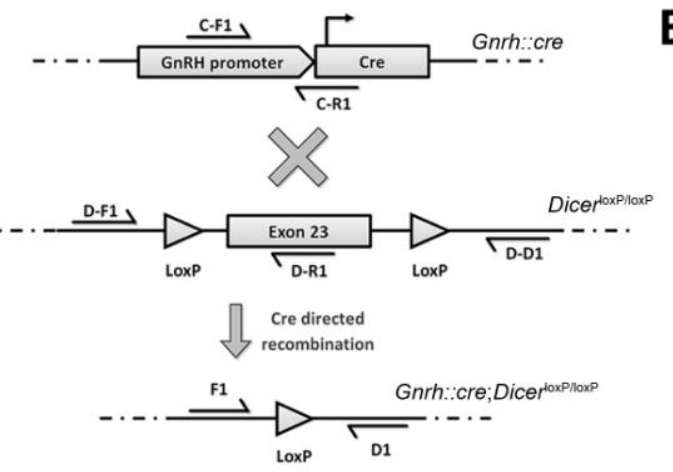

C
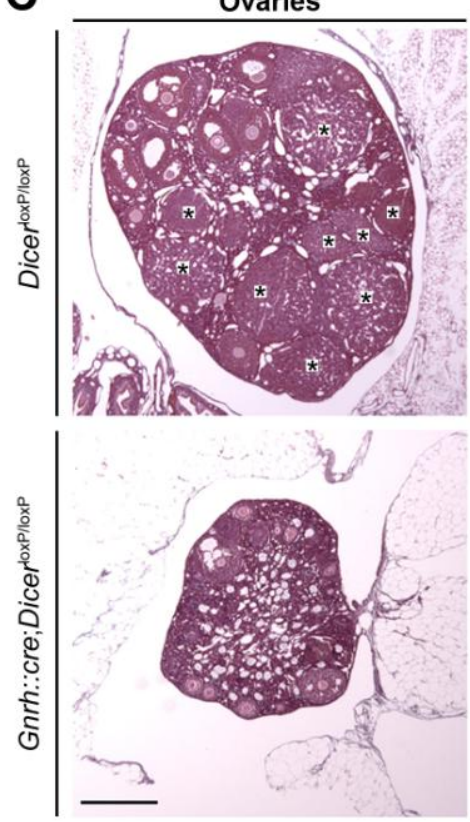

D

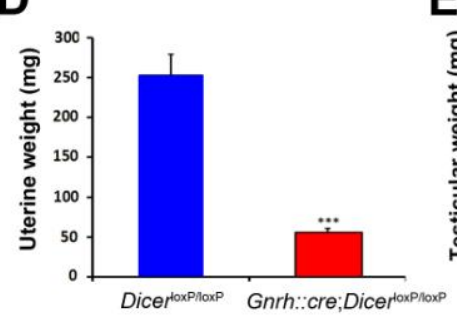

G

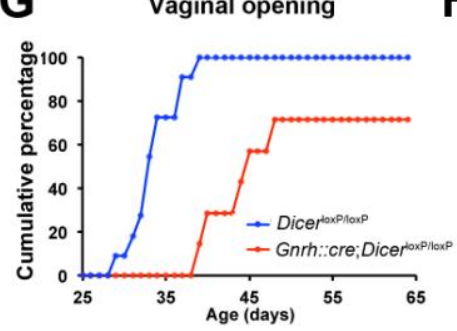

$E$

H
B

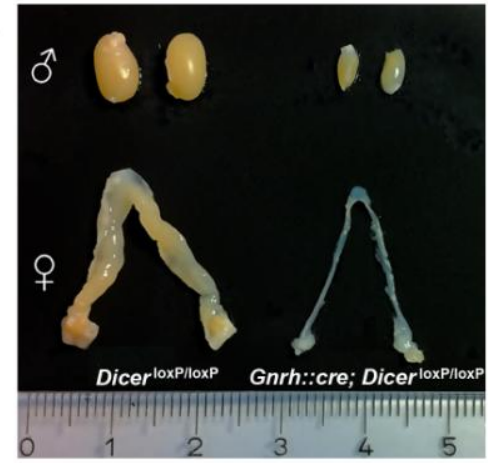

Testes
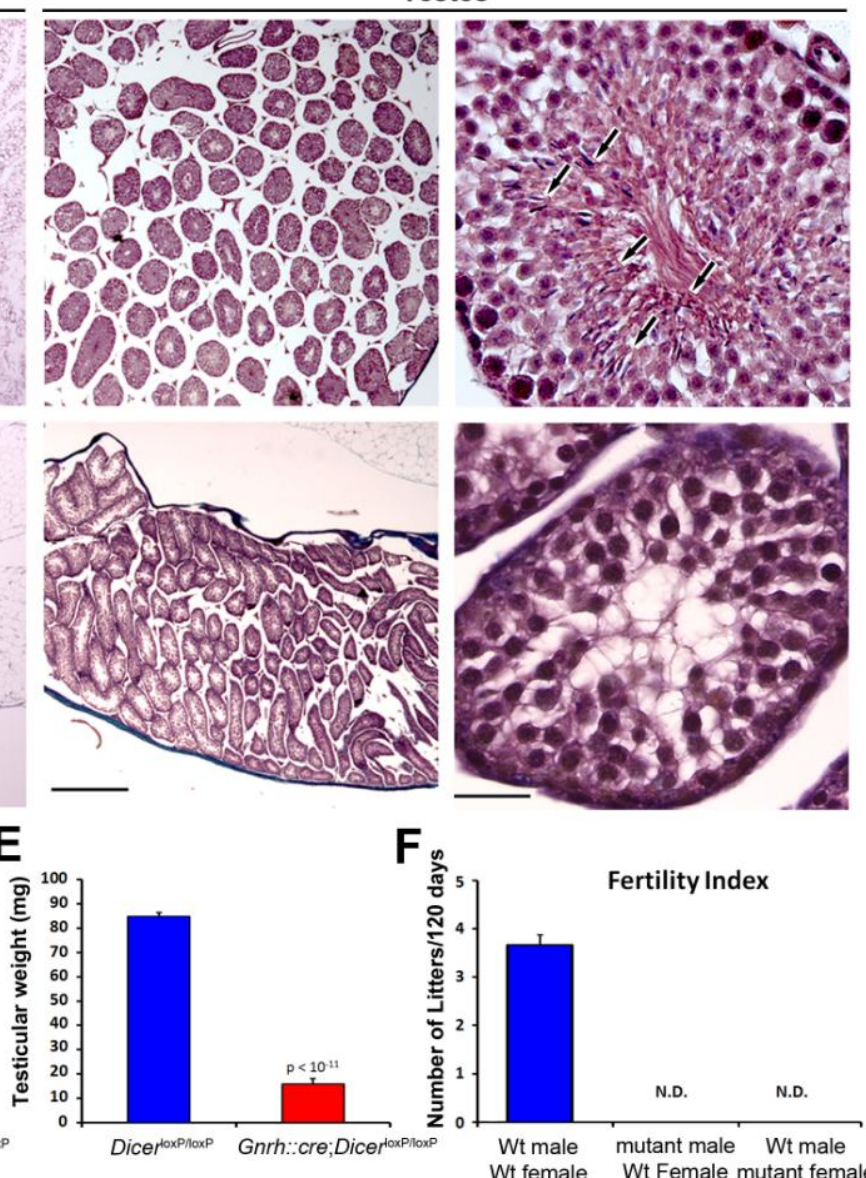

First estrus

1 Growth curve
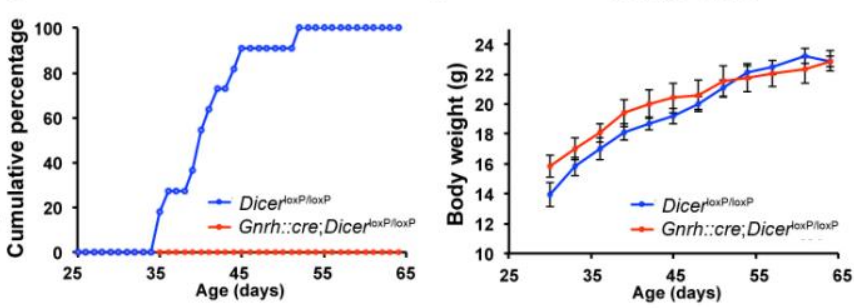

Figure 1. Lack of miRNA biogenesis in GnRH neurons leads to hypogonadotropic hypogonadism and infertility. (A) Genetic strategy to invalidate Dicer expression specifically in GnRH-expressing cells in mice. (B) Smaller testes and ovaries and thread-like 
uteri in mutant mice. (C) Hematoxylin-eosin-stained ovarian and testicular sections of mutant Gnrh::Cre; Dicer loxP/loxP mice and their wild-type Dicer ${ }^{\text {JoxP/loxP }}$ littermates. Asterisks show corpora lutea and arrows, spermatozoa. Scale bars: $500 \mu \mathrm{m}$ (left and middle panels) and 30 $\mu \mathrm{m}$ (right panels). (D to F) Both male and female Gnrh::Cre; Dicer ${ }^{\text {loxP/loxP }}$ mice exhibit hypogonadism and are infertile. N.D.: not detected. $\left({ }^{* * *}: p<0.001,{ }^{* \star * *}: p<0.0001\right)$. Values shown are mean \pm SEM. (G to J) While some Gnrh::Cre; Dicer ${ }^{\text {loxP/loxP }}$ female mice undergo vaginal opening during postnatal development $(\mathbf{G})$, they never reach puberty $(\mathbf{H})$ despite normal somatic growth (I). 

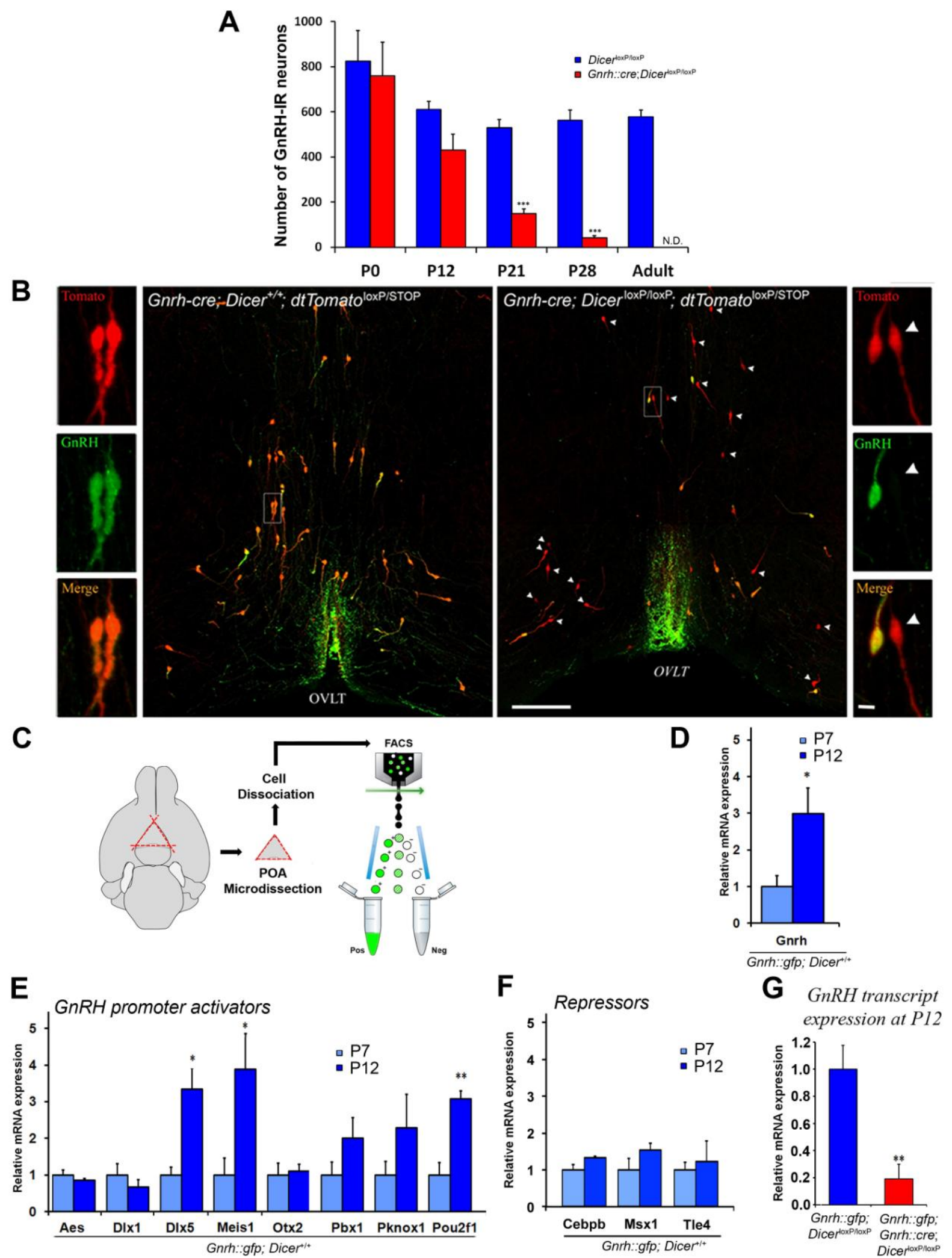

G GnRH transcript expression at $P 12$

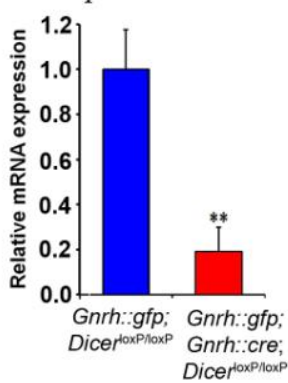

Figure 2. A switch in the control of GnRH gene expression is operated by miRNAs during postnatal developmental. (A) Gradual disappearance of $\mathrm{GnRH}$-immunoreactive $(\mathrm{GnRH}-\mathrm{IR})$ neurons in Gnrh::Cre; Dicer ${ }^{\text {loxP/loxP }}$ during postnatal development. $\left.{ }^{* * *}: \mathrm{p}<0.001\right)$. 
P0, postnatal day 0; N.D., not detected. (B) Neuronal lineage tracing shows normal distribution of $\mathrm{GnRH}$ neurons in P21 juvenile mice with $\mathrm{GnRH}$ deficiency (Gnrh::Cre; Dicer $^{\text {JoxP/loxP; }}$ tdTomato ${ }^{\text {loxP/STOP }}$, when compared to control littermates (Dicer ${ }^{\text {loxP/loxP; }}$ tdTomato ${ }^{\text {loxP/STOP }) . ~ A r r o w h e a d s ~ s h o w ~ G n R H-i m m u n o n e g a t i v e ~ T o m a t o-p o s i t i v e ~ n e u r o n s . ~}$ OVLT, organum vasculosum of the lamina terminalis. Scale bars, $200 \mu \mathrm{m} ; 10 \mu \mathrm{m}$ (inset). (C) GnRH-GFP neuron isolation by FACS from the preoptic region of Gnrh::Gfp mice. (D-H) Real-time PCR analysis of expression levels of $\mathrm{GnRH}$ mRNA (D, G), GnRH promoter activators $\left(D / x 5, \mathrm{t}_{(5)}=-3.62, \mathrm{p}=0.015 ;\right.$ Meis $1, \mathrm{t}_{(5)}=-3.67, \mathrm{p}=0.014 ;$ Pou2f1, $\mathrm{t}_{(5)}=-6.14, \mathrm{p}=0.0017$; $n=3-4$ per group) (E) and repressors (F) in FACS-sorted GnRH-GFP neurons. ((*: $p<0.05$; **: $\mathrm{p}<0.01)$. Values are expressed relative to P7 or wild-type values, as appropriate, set at 1. Values shown are mean \pm SEM. 
A

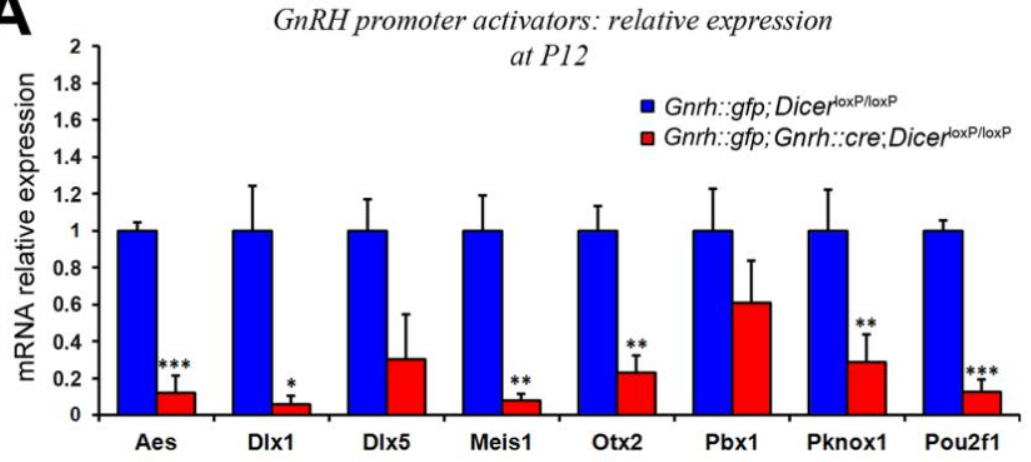

B

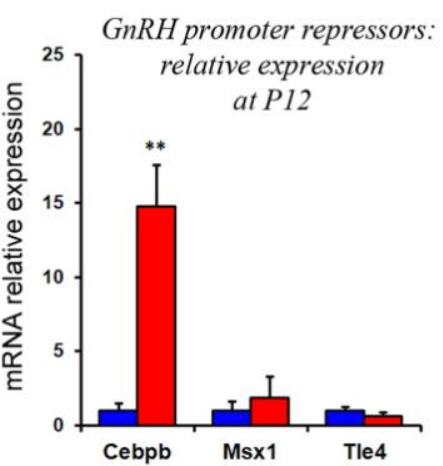

C

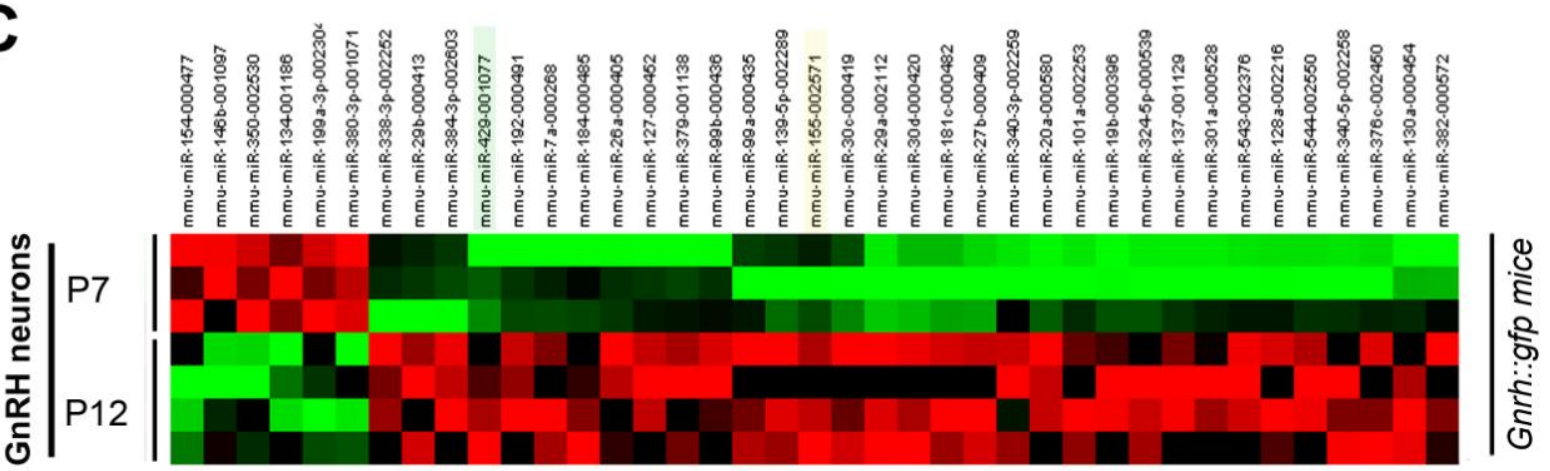

$\begin{array}{lllllll}30 & -20 & -10 & 1 & +10 & +20 & +30\end{array}$

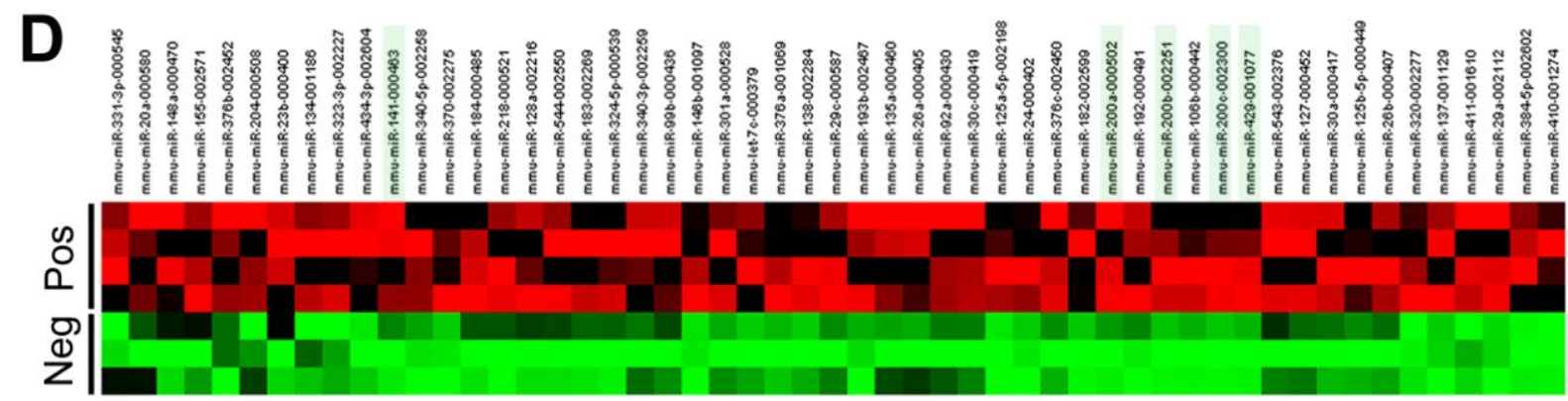

$\mathbf{E}$

Expression of miR-200 family members in GnRH and non-GnRH cells at P12

$\mathbf{F}$

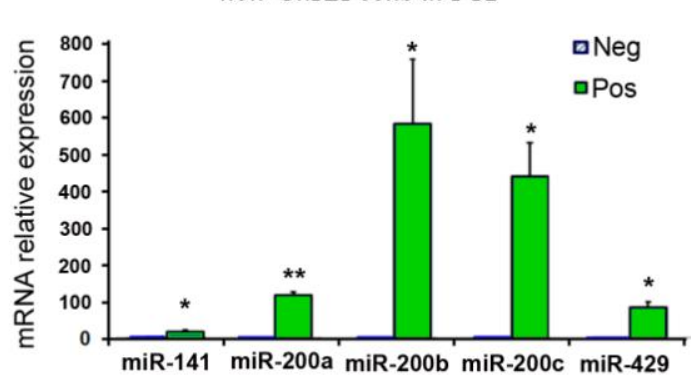

Expression of miR-200 family members in GnRH neurons at $P 7$ and P12

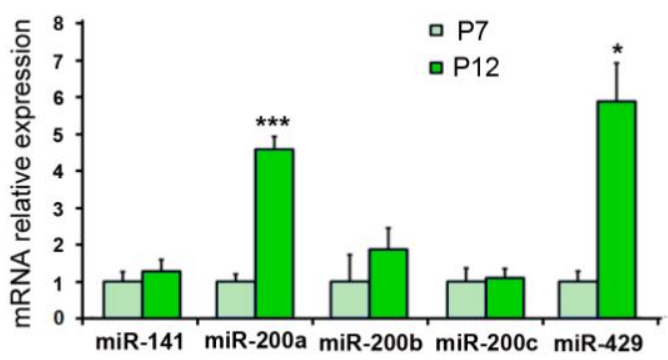

Figure 3. MiRNAs regulate the expression of $\mathrm{GnRH}$ promoter modulators in infantile

GnRH neurons. (A and B) RT-PCR analysis of the expression of GnRH promoter activators (A) and repressors (B) in FACS-sorted GnRH-GFP neurons from mice selectively lacking 
Dicer in GnRH neurons (red bars) or wild-type for Dicer (blue bars) (all values are expressed relative to wild-type values, set at 1). Aes, $\mathrm{t}_{(5)}=9.58, \mathrm{p}=0.0002 ; D / x 1, \mathrm{t}_{(5)}=3.78, \mathrm{p}=0.032$; Meis1, $\mathrm{t}_{(3.17)}=4.71, \mathrm{p}=0.018 ;$ Otx2, $\mathrm{t}_{(5)}=4.34, \mathrm{p}=0.0074 ;$ Pou2f1, $\mathrm{t}_{(5)}=10, \mathrm{p}=0.0002 ; \mathrm{n}=3-4$ per group. Pknox $1, \mathrm{t}_{(6)}=2.63, \mathrm{p}=0.039 ;$ Cebpb, $\mathrm{t}_{(3.17)}=-4.79, \mathrm{p}=0.0173, \mathrm{n}=4$ per group $\left(^{*}: \mathrm{p}<0.05\right.$; $\left.{ }^{* *}: p<0.01 ;{ }^{* * *}: p<0.001\right)$. (C-D) miRNAs whose expression changes between P7 and P12 (C) and that are specifically enriched in GnRH neurons at P12 (D). Pos: GFP-expressing neurons; Neg: GFP-negative cells. (E and F) RT-PCR analysis of the expression of miR-200 family members in FACS-sorted cells from preoptic explants isolated from Gnrh:Gfp mice wild-type for Dicer either at P12 (E; Pos vs. Neg: miR-141, $\mathrm{t}_{(5)}=3.370, \mathrm{p}=0.0199$; miR-200a, $t_{(4)}=13.57, p=0.0002 ; m i R-200 b, t_{(5)}=2.775, p=0.0391 ; m i R-200 c, t_{(5)}=4.016, p=0.0102 ; m i R-$ 429, $\mathrm{t}_{(5)}=4.778, \mathrm{p}=0.005 ; \mathrm{n}=3-4$ per group) or at $\mathrm{P} 7$ and $\mathrm{P} 12$ (F; P7 vs. P12: miR-141, $\mathrm{t}_{(5)}=0.6652, \quad \mathrm{p}=0.5354 ; \quad \operatorname{miR}-200 \mathrm{a}, \mathrm{t}_{(4)}=9.178, \mathrm{p}=0.0008 ; \quad \operatorname{miR}-200 \mathrm{~b}, \mathrm{t}_{(5)}=0.9572, \mathrm{p}=0.3824$; miR-200c, $t_{(5)}=0.2604, p=0.805 ; m i R-429, t_{(5)}=3.931, p=0.0111 ; n=3-4$ per group). Values shown are mean \pm SEM. 


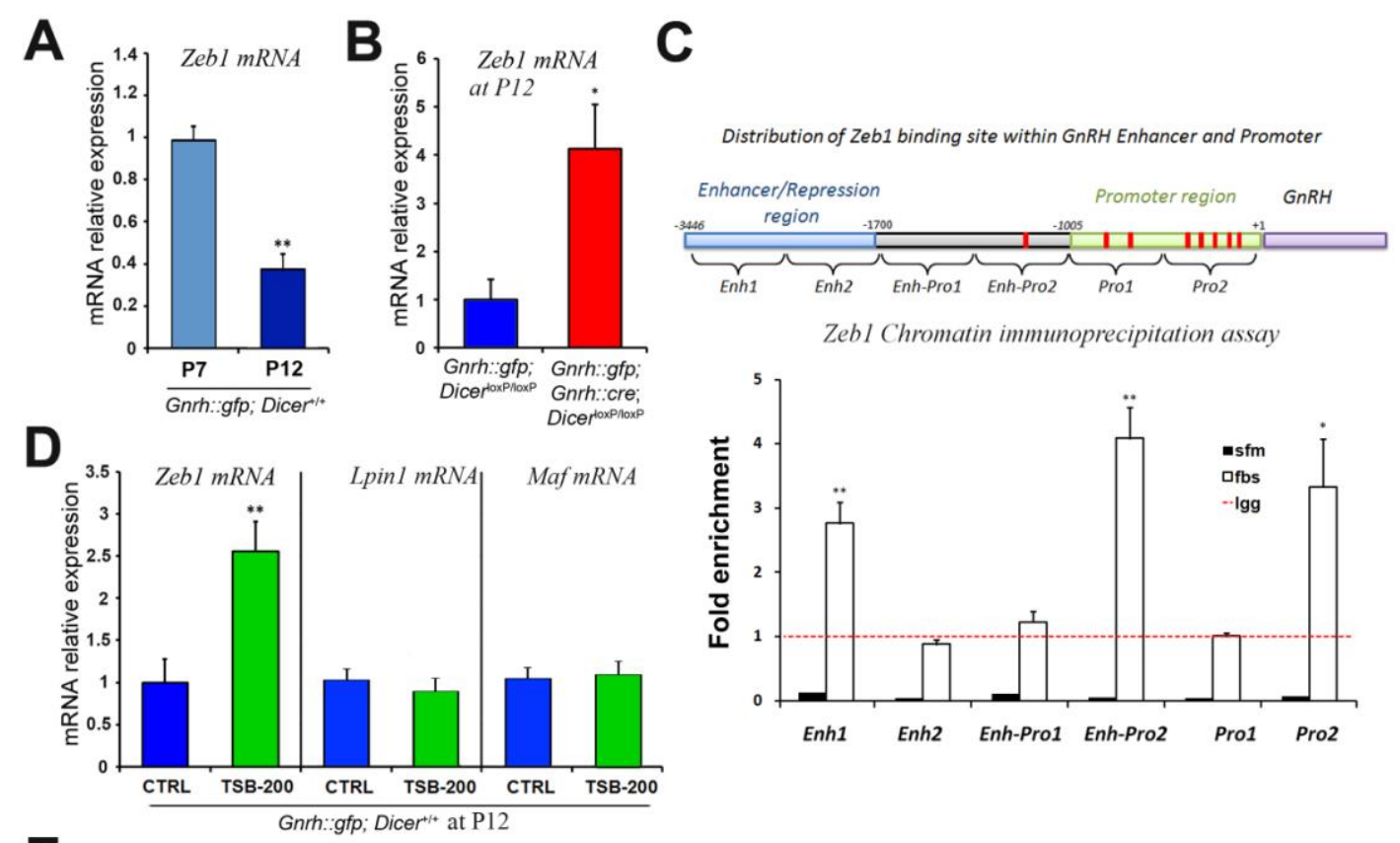

$\mathbf{E}$
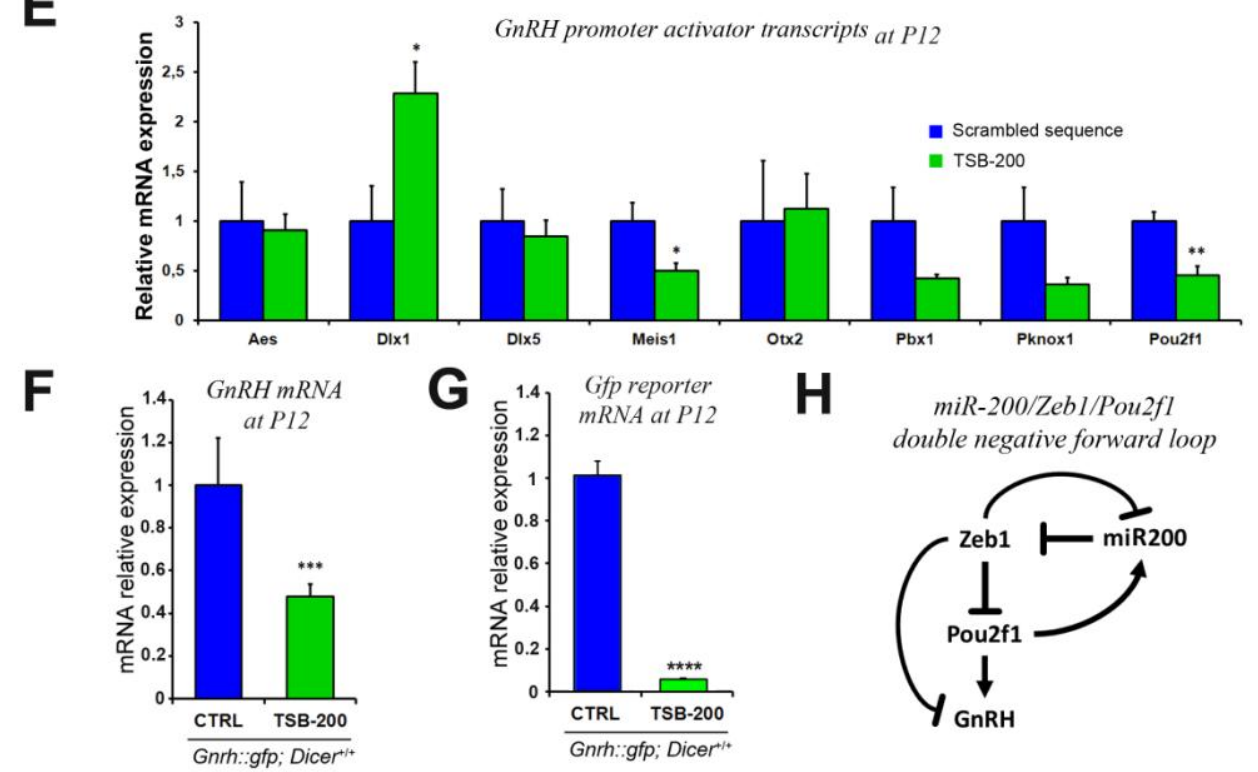

Figure 4. Knocking down the ability of miR-200 to repress Zeb1 expression in the brain alters infantile GnRH promoter activity and Gnrh mRNA expression. (A and B) RT-PCR analysis of the expression of Zeb1 in GnRH-GFP neurons isolated from Gnrh::Gfp; Dicert+t mice at P7 and P12 (A) or from mice in which Dicer expression is invalidated or not in $\mathrm{GnRH}$ neurons (B). (C) Diagram showing the distribution of putative Zeb1 binding sites on the Gnrh gene (upper panel) and their validation using a Zeb1 chromatin immunoprecipitation assay in an immortalized mouse cell line secreting GnRH and cultured in the presence or absence of fetal bovine serum (fbs). Values are expressed relative to the immunoprecipitation of chromatin containing the $\mathrm{GnRH}$ promoter region with irrelevant IgG species, arbitrarily set at 
1 (red dotted line). Serum-free medium (sfm) vs. fbs: Enh1, $\mathrm{t}_{(6)}=4.756, \mathrm{p}=0.0031$; Enh2, $\mathrm{t}_{(6)}=2.320, \mathrm{p}=0.0595 ;$ Enh-Pro1, $\mathrm{t}_{(6)}=0.9063, \mathrm{p}=0.3997 ;$ Enh-Pro2, $\mathrm{t}_{(6)}=5.462, \mathrm{p}=0.0016 ;$ Pro1, $\mathrm{t}_{(6)}=0.2104, \mathrm{p}=0.8403 ;$ Pro2, $\mathrm{t}_{(6)}=2.467, \mathrm{p}=0.0486, \mathrm{n}=4$ per group. (D-G) Effect of the i.c.v . injection of TSB-200 (green bar) or a scrambled sequence (CTRL, blue bar) on the expression of Zeb1, Lpin1 and Maf (D), mRNA for GnRH promoter activators $\left(D / x 1, \mathrm{t}_{(8)}=-\right.$ 2.63, $\mathrm{p}=0.03, \mathrm{n}=4-6$ per group) $(\mathbf{E}), \mathrm{GnRH}$ transcript $(\mathbf{F})$ and $\mathrm{GnRH}$ promoter activity $(\mathbf{G})$ in GnRH-GFP neurons of infantile mice of 12 days of age. (H) Putative double negativefeedback loop illustrating the potential contribution of mir200, Zeb1 and Pouf2f1, which are both known to control the expression of the former in the infantile control of $\mathrm{GnRH}$ gene expression (see also Fig. S7A). Values are expressed relative to P7, wild-type or control values, as appropriate, set at $1 .\left({ }^{*}: p<0.05 ;{ }^{* *}: p<0.01\right)$. Values shown are mean \pm SEM. 
A

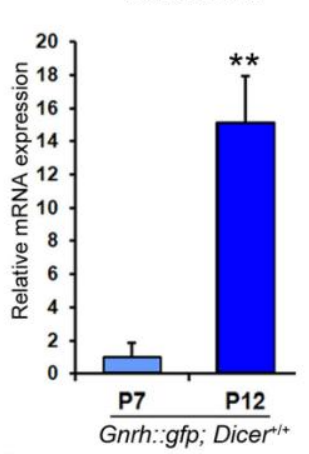

C

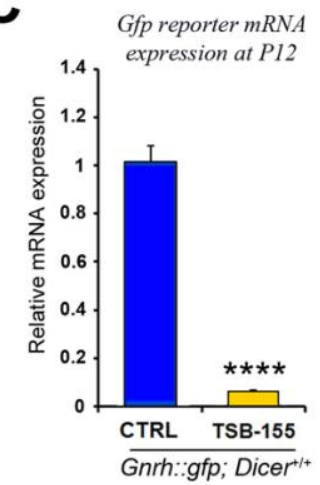

$\mathbf{F}$

miR-200/miR-155 convergent regulation of Kiss 1/Gpr54 signalling
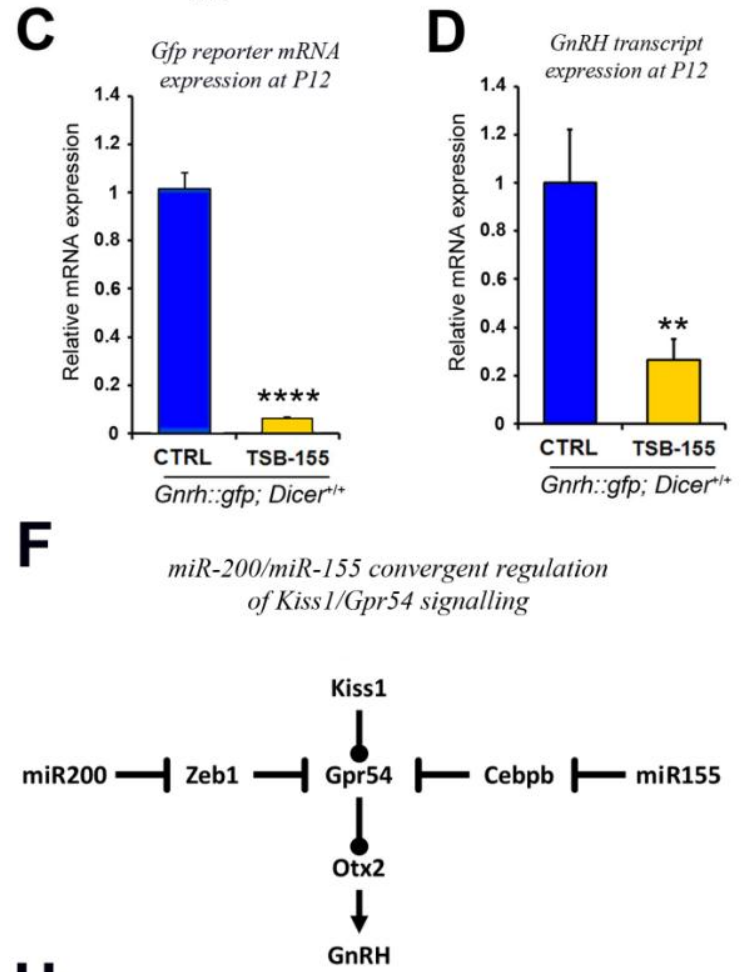

B Cebpb transcript Lpinl transcript Maftranscript

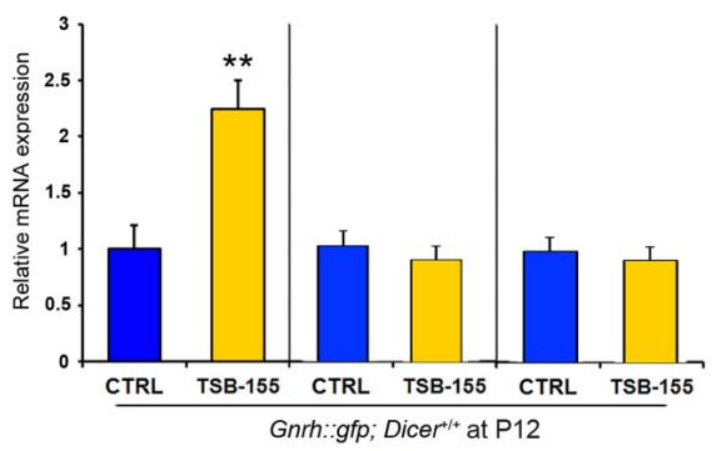

G
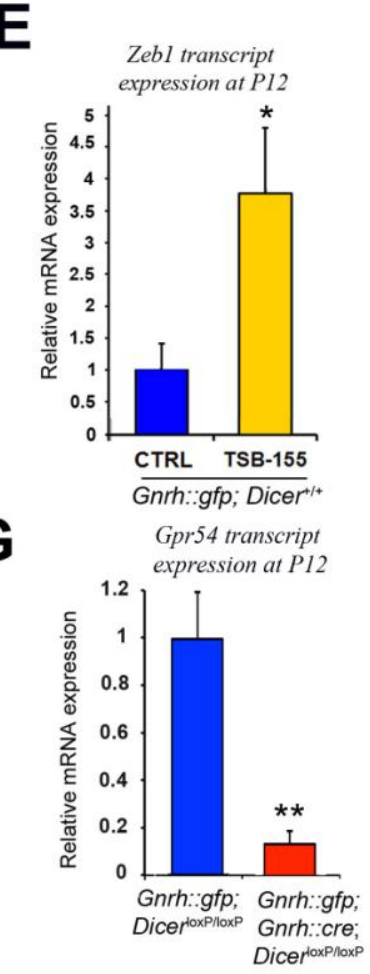

H p-nNos nNOS actin

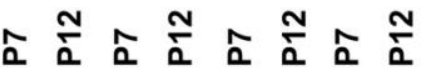

I

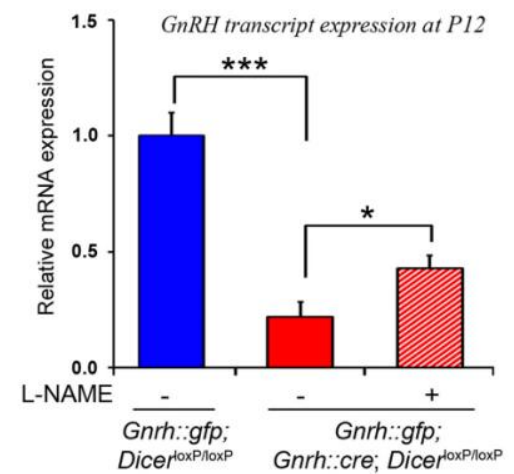

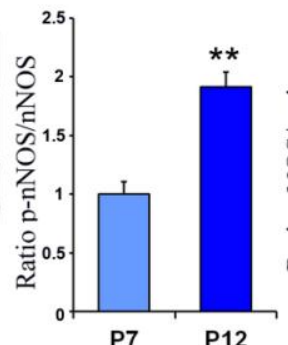

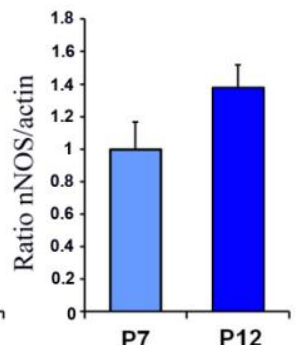

J

miR-155 inhibition of $\mathrm{NO} / \mathrm{Cebpb}$ dependent repression

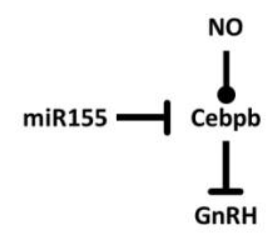


Figure 5. miR-155 modulates Cebpb, Gnrh and Zeb1 mRNA expression in infantile GnRH neurons. (A) RT-PCR analysis of the expression of miR-155 in FACS-isolated GnRHGFP neurons between P7 and P12 (**: p<0.01). (B-E) Effect of the i.c.v. injection of TSB-155 (yellow bar) or a scrambled sequence (Ctrl, blue bar) on the expression of Cebpb, Lpin1 and Maf (B), GnRH promoter activity (C), and GnRH (D) and Zeb1 (E) transcripts in GnRH-GFP neurons of infantile mice. (F) Putative miRNA-gene network illustrating the convergent contributions of miR200 and miR155, and their respective target genes Zeb1 and Cebpb, in the infantile control of $\mathrm{GnRH}$ expression via the repression of the kisspeptin/Gpr54/Otx2signaling pathway (see also Fig. S7A and S9). (G) RT-PCR analysis of expression levels of Gpr54 mRNA in FACS-sorted GnRH-GFP neurons $\left({ }^{* *} \mathrm{p}<0.01\right)$. (H) Western blot (upper panel) and quantitative (bottom panel) comparison of phosphorylated and total nNOS protein expression in the preoptic region of wild-type mice between P7 and P12. Actin was used as a loading control. Values are expressed relative to P7, set at 1. (I) L-NAME treatment partially rescues $\mathrm{GnRH}$ mRNA expression in P12 mice harboring a Dicer deficiency in $\mathrm{GnRH}$ neurons. (J) Schematic representation of a miRNA-gene network potentially regulating $\mathrm{GnRH}$ expression in the infantile period, and its crosstalk with nitrergic neurotransmission. ( $p<0.05 ;^{* \star *}: p<0.0001, t_{(10)}=6.66, n=6$ per group). Values are expressed relative to untreated wild-type values, set at 1 . Values shown are mean \pm SEM. 
A

Age at puberty (first estrus)

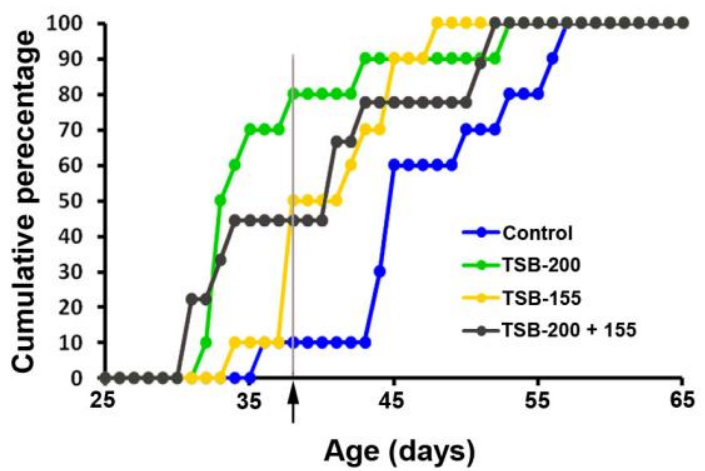

C

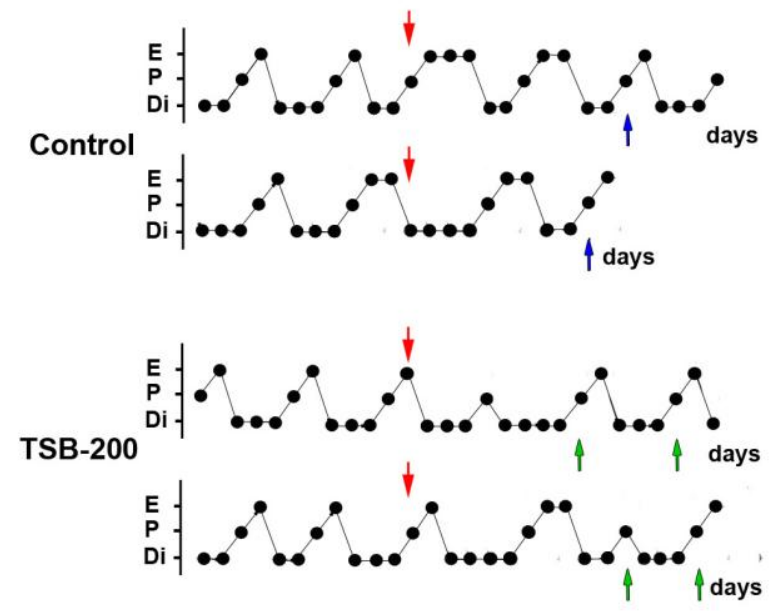

B Peripubertal LH levels

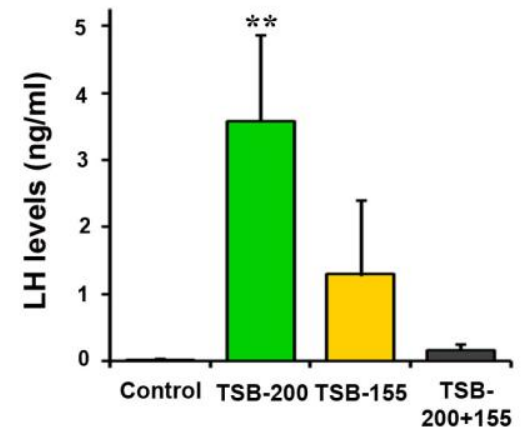

D Preovulatory LH levels

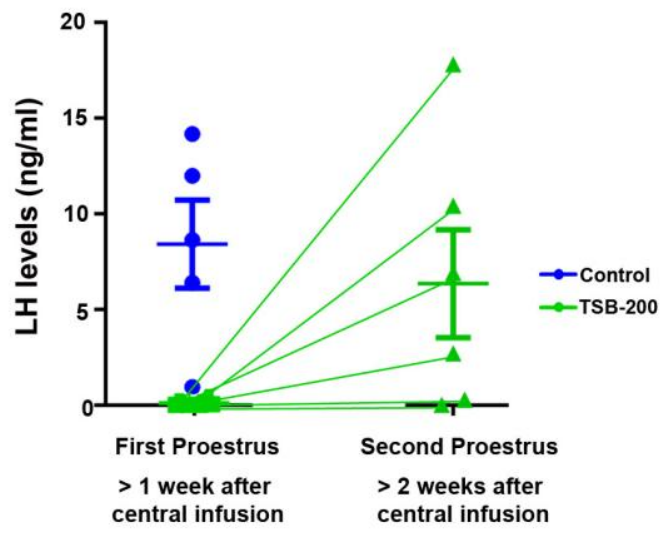

Figure 6. miR-200 binding to Zeb1 modulates the function of GnRH neurons both in infantile and adult mice. (A) Knocking down the ability of miR-200 and/or miR-155 to repress Zeb1 and Cebpb expression, respectively, during the infantile period markedly accelerates puberty. (B) Circulating levels of LH in P38 peripubertal mice (arrow in A), in which TSB-200, TSB-155, TSB-200+155 or scrambled control sequences were infused into the brain during the infantile period $\left({ }^{*}: p<0.01\right)$. (C) Estrous cyclicity before and after the infusion of TSB-200 into the preoptic region of adult mice (red arrows). Upward arrows show the time of blood collection in control- (blue) and TSB-200-treated (green) mice. (D) LH levels in blood samples collected during proestrus as indicated in C. Values shown are means \pm SEM. 


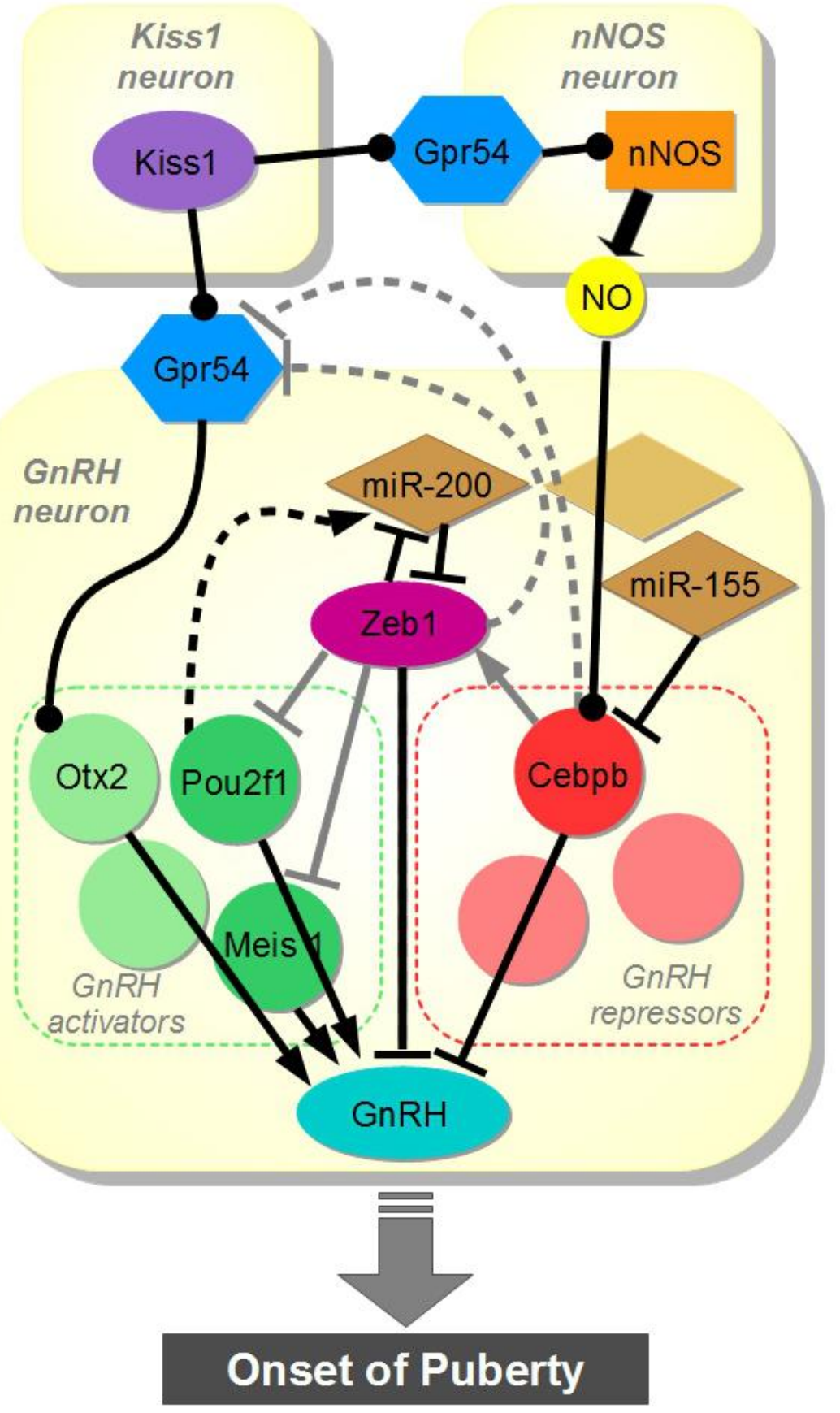

Figure 7. Neuronal microcircuit and miRNA-gene network in hypothalamic GnRH neurons regulating the onset of puberty. Schematic diagram illustrating the potential contribution of the miR-155 and miR-200 families and their target genes to the increase in 
$\mathrm{GnRH}$ gene expression during the infantile period of postnatal development and how these events may be intertwined with the integration of postmigratory $\mathrm{GnRH}$ neurons into the neural network responsible for regulating the timely onset of puberty (solid lines: demonstrated/published; grey lines: ChipSeq data; dotted lines: predictive in silico analyses). 